\title{
On-farm management and participatory evaluation of pigeonpea (Cajanus cajan [L.] Millspaugh) diversity across the agro- ecological zones of the Republic of Benin
}

\section{Géofroy KINHOEGBE ( $\nabla$ dongeofroy@gmail.com )}

University of Abomey-Calavi https://orcid.org/0000-0002-5598-708X

\section{Gustave Djèdatin}

BIOGENOM Laboratory, Faculty of Sciences and Technology of Dassa (FAST-Dassa), National University of Sciences

Technologies Engineering and Mathematics of Abomey (UNSTIM)

Laura Estelle Yêyinou Loko

Laboratoy of Applied Entomology, FAST-Dassa,UNSTIM

Abraham Gnimansou Favi

University of Abomey-Calavi

Aristide Adomou

University of Abomey-Calavi

\section{Clément Agbangla}

Laboratory of molecular genetics and genomes analysis, University of Abomey-Calavi

\section{Alexandre Dansi}

Laboratory of Biotechnology, Genetic Ressources and Plant and Animal breeding (BIORAVE), FAST-Dassa

\section{Research}

Keywords: Benin, On-farm management, Participatory evaluation, Pigeonpea, Preference criteria, Production constraints

Posted Date: May 18th, 2020

DOI: https://doi.org/10.21203/rs.2.19119/v4

License: (c) (1) This work is licensed under a Creative Commons Attribution 4.0 International License. Read Full License

Version of Record: A version of this preprint was published at Journal of Ethnobiology and Ethnomedicine on May 13 th, 2020. See the published version at https://doi.org/10.1186/s13002-020-00378-0. 


\section{Abstract}

Background: Pigeonpea is a multipurpose food legume crop that contributes to food security in the Republic of Benin. For the establishment of conservation and breeding programs, previous ethnobotanical surveys on pigeonpea were done in Benin but restricted to south and central regions. In previous years, pigeonpea landraces were introduced in northern Benin for soil fertility management; it is therefore important to evaluate the diversity in this legume in this region. Exhaustive documentation of pigeonpea diversity grown in the Republic of Benin will be necessary for effective breeding and conservation programs. Therefore, the aim of this study was to document genetic diversity of pigeonpea, across the agro-ecological zones of the Republic of Benin for its promotion and valorization.

Methods: A total of 500 pigeonpea farmers representing thirteen sociolinguistic groups were selected from 50 villages. The data were collected using methods and tools of participatory research appraisal. Folk nomenclatures, taxonomy of pigeonpea and seed system were investigated. The distribution and extent of pigeonpea landraces were evaluated using the Four Square Analysis method. A comparative analysis of pigeonpea use categories production systems, production constraints, famers' preference criteria and participative evaluation for existing landraces across agro-ecological zones was done.

Result: Folk nomenclature and taxonomy were mainly based on seed coat colour and size. Seven pigeonpea use categories were recorded including sacrifice, grain processing and fertilization. The results showed that the pigeonpea seed system is informal. Based on seed characteristics, fifteen landraces were recorded including seven new landraces. The Sudano-Guinean zone contained the highest number (11) of landraces. The average number of landraces per village was 2.7. A high rate of landraces facing threat of disappearance was observed across the ecological zones. Ten constraints are known to affect pigeonpea production in Benin, with pests and diseases as the most critical in all agro-ecological zones. This study revealed that pigeonpea cultivation is increasing in the Sudanian zone. Varieties to be produced must be selected based on 11 criteria which included precocity and resistance to pests and diseases in the three ecological zones and adaptability to any type of soil in the Sudanian zone. The participatory evaluation revealed the existence of a few performing cultivars.

Conclusions: Our results revealed that implementation of a pigeonpea genetic conservation program in Benin must take into account the diversity, production constraints and varietal preference, which varied according to agro-ecological zones. In situ and ex situ conservation strategies are important to preserve pigeonpea landraces. Morphological and molecular characterizations of identified cultivars are highly recommended to help select suitable varieties for breeding programs.

\section{Background}

Pigeonpea (Cajanus cajan [L.] Millspaugh) is a multipurpose food legume, serving as a lifeline to resource-poor farmers in tropical and subtropical regions of Asia, Africa, and Latin America [1]. Pigeonpea is an excellent source of protein $(21.7 \mathrm{~g} / 100 \mathrm{~g})$, dietary fibers $(15.5 \mathrm{~g} / 100 \mathrm{~g})$, soluble vitamins, minerals, and essential amino acids [2, 3]. Moreover, it is also used in traditional medicines, as its leaves, flowers, roots and seeds are used for the cure of bronchitis, sores, respiratory ailments. It also acts as an alexeritic, anthelmintic, expectorant, sedative, and vulnerary $[4,3]$.

In Benin, pigeonpea is widely consumed in the South-East by the Adja cultural area and contributes to the increase of household incomes [5]. The plant is used for soil conservation and weed management in the fields [6, 7, 5]. Despite the importance of pigeonpea [5], very few research efforts have been undertaken to improve the production of the species. As a result, the potential yield of pigeonpea is estimated at 2,500 kg/ha, while the yields obtained on farmers' fields is estimated at $620 \mathrm{~kg} / \mathrm{ha}$ in Benin [8] This low yield could be due to the lack of improved varieties in Beninese agriculture [9]. Therefore, an exhaustive collection of cultivated pigeonpea diversity at the country level is the basis for the development of any varietal improvement program and the implementation of conservation strategies.

Several studies have been conducted on pigeonpea diversity in Benin. However, all previous investigations on pigeonpea in Benin were restricted to South and Central Benin $[9,10,11,12]$. These studies reported 7 [11] and 8 [9] pigeonpea landraces with significant differences of diversity across the socio-linguistic groups and decreased production of this legume in Benin [11]. However, there is no data related to pigeonpea diversity and its production constraints in northern Benin although, pigeonpea

Page $2 / 31$ 
landraces were introduced in this region for soil fertility management during recent years [13]. In addition, no comparative study on pigeonpea production constraints across different ecological zones in Benin has been documented; varietal diversity as well as farmers' varietal preference criteria and their variation throughout ecological zones and sociolinguistic groups have very little documentation. While it is known that understanding the genetic diversity, uses, and distribution of orphan crops is essential in determining what to conserve and where to conserve, for sustainable utilization $[14,15,16]$, it is also important to have a comprehensive collection of pigeonpea genetic resources of the Republic of Benin and to record all associated ethnobotanical knowledge by extensive survey $[9,11]$.

Seeds are the lifeblood and foundation of successful farming and a crucial element in the lives of agricultural communities [15]. The procedures whereby a cultivar is bred, produced, certified, stored, marketed and used, which includes all the channels through which farmers acquire genetic materials and the interaction with the commercial seed industry, is known as a seed system [16]. Therefore, the success of introduced crop varieties is tightly linked to the uses, biophysical conditions and the cropping systems in which the crop is integrated which vary across growing areas [10]. Folk taxonomy is a pre-scientific type of naming and classification system rooted in culture [17]. Thus, folk taxonomy is specific to each culture. As a result, vernacular names have a very local distribution and may change with time because of incidental events and contact with other languages [18]. However, folk taxonomy or traditional classification of crop landraces is essential, as these are the basic units that farmers manage, to select and diversify their crops [11]. The knowledge of folk nomenclature and taxonomy is essential for communicating pigeonpea usage in local communities. Unfortunately, pigeonpea folk taxonomy and nomenclature in Benin is restricted [9, 11]. This information is however vital, among others, for developing seed distribution and establishment of regional varietal map [19].

In developing countries where agriculture is the spearhead of the economy, improved varieties must be developed or simply discovered within the existing diversity. In both cases, a good knowledge of the existing varietal diversity and the agronomic performance of varieties are necessary [20,21]. Hence, farmers participation in the varietal selection process determines variety adoption [22]. Moreover, documentation and identification of high-performing cultivars based on farmers' varietal preference criteria will provide strategies to overcome constraints affecting pigeonpea production in Benin. Consequently, it is important to evaluate the performance of existing pigeonpea landraces under participatory approaches to enhance pigeonpea production and productivity, thereby contributing to the attainment of food security and poverty reduction.

Therefore, this study has been designed with following aims: (1) to document different landraces, local nomenclature and folk taxonomy of pigeonpea grown in Beninese agriculture, (2) to compare seed management and conservation systems of pigeonpea genetic resources and use categories across different ecological zones, (3) to compare constraints associated with pigeonpea production and varietal preference criteria across different ecological zones and sociolinguistic groups and (4) to evaluate using participatory approaches the performance of different landraces in relation to agronomic and culinary traits.

\section{Methods}

\section{Study area}

The study was carried out in Benin. With a population of 10,008,749 [23], Benin is located in the intertropical zone between parallels $6^{\circ} 30^{\prime}$ North and $12^{\circ} 30^{\prime}$ North latitude, and meridians $1^{\circ}$ East and $30^{\circ} 40^{\prime}$ East longitude [24]. With an area of 114,763 $\mathrm{km}^{2}$, Benin is bordered in the north by the Niger River in the northwest by Burkina Faso, in the west by Togo, in the south by the Atlantic Ocean and in the east by the Nigeria (Figure 1). The Republic of Benin is divided into three ecological zones: the Guinean zone $\left(6^{\circ} 25^{\prime}\right.$ North latitude and $7^{\circ} 30^{\prime}$ North longitude) in the South, the Sudano-Guinean zone $\left(7^{\circ} 30^{\prime}\right.$ North latitude and $9^{\circ} 45^{\prime}$ North longitude) in the Central, and the Sudanian zone ( $9^{\circ} 45^{\prime}$ North latitude and $12^{\circ} 25$ North longitude) in the north [25]. The Guinean and Sudano-Guinean zones are both located in a moist agro ecological zone characterized by a subequatorial bimodal climate with two dry seasons and two rainy seasons. The Guinean zone is characterized by an annual rainfall varying between 1200 and $1500 \mathrm{~mm} /$ year. The temperature ranges from 24 to $30^{\circ} \mathrm{C}$. The Sudano-Guinean zone annual rainfall varies from 1100 to 1300 $\mathrm{mm}$ /year (Table 1). The temperature in this zone varies between 25 and $34^{\circ} \mathrm{C}$. The Sudanian zone is located in the semi-moist agro ecological zone characterized by a unimodal climate pattern with one rainy season and one dry season. The annual rainfall varies between 900 and $1100 \mathrm{~mm} /$ year while the temperature ranges from 21 to $35^{\circ} \mathrm{C}$ [25] (Table 1). 
After an exploratory study in agricultural research institutions, visits to local and urban markets, discussion with farmers and sellers, surveyed villages were selected based on their pigeonpea production, accessibility and the ability to cover the maximum sociolinguistic groups. A total of 50 villages were selected and included in the survey (Figure 1).

\section{Data collection}

Surveys were conducted using different methods (group discussions, individual interviews, and field visits) and tools (questionnaires) of participatory research appraisal following Dansi et al. [26].

\section{Focus groups}

In each village, groups of 15 to 28 farmers were identified and brought together with the help of administrative and/or local authorities (village chief, farmers' associations, etc.). Interviews were conducted using local translators to facilitate discussions [27]. Prior to the meetings, farmers were asked to bring samples of pigeonpea landraces they cultivate or knew about. After a brief presentation of the research objectives to the farmers, they were asked to list in vernacular, the names of all pigeonpea landraces cultivated in the village. The distribution and extent of these landraces were evaluated using the participatory method of Four Square Analysis described by Brush [28]. This method allows classifying existing landraces into four groups (produced by many households on large areas, produced by many households on small areas, produced by small households on large areas and produced by few households on small areas). We agreed with the farmers that a landrace cultivated by few households is one grown by no more than $20 \%$ of farmers in the context of the village; and a landrace cultivated on a small area is one cultivated on no more than $0.25 \mathrm{ha}$. The participatory evaluation of identified landraces for agronomic and culinary traits was carried out according to Gbaguidi et al. [29]. The parameters considered were productivity, vegetative cycle, cooking time, sensitivity to pests and disease and sensitivity to storage insects. The two-level evaluation method described by Loko et al. [30] was used. In this approach, for a given trait, a landrace is scored 1 when it shows good performance and 0 when it shows bad performance. After that, local nomenclature, folk taxonomy and the vegetative cycle of landraces were documented.

According to Dansi et al. [31], farmers were asked to list all the constraints associated with pigeonpea production. These constraints were prioritized in groups by identifying and gradually eliminating the most severe constraint. As a first step, farmers were asked to identify, among the constraints they have listed, the most critical. The identified constraint is ranked first and eliminated from the list. The same procedure is repeated until the last constraint was ranked. Secondly, farmers were asked to list all the traits that could interest and motivate them to continue growing pigeonpea. Using the same approach (gradual elimination of the most important criterion), the identified criteria were then prioritized. The discussions were free, open-ended and without a set time limit.

\section{Household surveys}

After the group discussions, ten households in each selected village were identified for individual interviews. In each household, the person interviewed was chosen based on common agreement from the host couple according to Christinck et al. [32]. A total of 500 pigeonpea producers were surveyed throughout the study area. Socio-demographic characteristics (gender, educational level, age, experience, household size), biophysical resources (cropping area, source of labour), cultural practices (sowing period, plant types, land fertilization, pest and disease management, farming activities) and seed system (number of cultivated landrace, sowing time, plant type, land type, perception about the evolution of pigeonpea cultivation, fertilization, sources of labour, level of intervention in the production chain, pests and diseases incidence and its management and pigeonpea cropping areas for 2015, 2016 and 2017) were recorded. The reasons for pigeonpea production, the different pigeonpea use categories, pest incidence and its management were also documented. According to their incidence pattern, pest incidence was categorized by farmers as negligible (none), low, average, high, and very high. Incidence was categorized as negligible when pests appeared in very low number while it was categorized as low when infestation was responsible for growth retardation and high when infestation involves damage to flowers or pods and very high when infestation are responsible for death of plant.

\section{Data analysis}


Descriptive statistic was used to analyze data. To avoid overestimation of pigeonpea diversity in each ecological zone, connections between vernacular names were made based on the seed characteristics (seed color, color pattern, pigmentation color and the seed eye color) according to Mohammed et al. [33], Ayenan et al. [9] and Zavinon et al. [11]. The frequency of disappearance (FD) of each landrace was calculated using the following formula:

$\mathrm{FD}=(\mathrm{z} / \mathrm{Z}) * 100$

Where $z=$ Number of landraces threatened to disappear (cultivated by few households on a small areas) and $Z=$ Total number of landraces identified in the specific ecological zone.

In order to facilitate comparisons and to reduce outliers, from one ecological zone to another, reasons for pigeonpea cultivation and different uses (seed or other plant parts) were categorized [34,35]. The Fidelity Level of each category of reason and use was calculated on the scale of each ecological zone according to Akohoué et al. [14]. The Fidelity Level (FL) was calculated according to the formula described by Friedman [36]:

$\mathrm{FL}=(\mathrm{F} / \Sigma \mathrm{F}) * 100$

Where $\mathrm{F}=$ Number of respondents for a given modality of use or reason that motivates pigeonpea cultivation and $\Sigma \mathrm{F}=\mathrm{Sum}$ of the number of respondents for all modalities of use or reason.

The constraints were prioritized at the level of each ecological zone and the overall study area on the basis of the average of the following three parameters: the total number of villages in which the constraint is cited (TNV), the number of villages where the constraint is the major one or ranked first (MAC), and the number of villages in which the constraint was classified among the principal constraints (PCO) i.e. among the first five. For each of these parameters, a high value indicates an importance for the constraint. Thus, the importance of the constraint (IMC) is determined by the formula described by Dansi et al. [30]:

$\mathrm{IMC}=(\mathrm{NTV}+\mathrm{MAC}+\mathrm{PCO}) / 3$

The same approach was used to rank farmers varietal preference criteria. To compare the data (Socio-demographic characteristics, biophysical resources, cultural practices and seed system) reported in percentage of responses or in average, Analysis of Variance (ANOVA) and Tukey test was used for quantitative variables using Minitab 16 Software while the bilateral Z test was used for qualitative variables using Statistica 7.1 Software.

For an incidence modality of pests incidence on pigeonpea yield percentage of responses was compared from one ecological zone to another by using bilateral Z test. In order to determine potential significant changes in the cropping area from 2015 to 2017, Analysis of Variance was conducted at the scale of the study area and within each ecological zone. Before ANOVA, data were log-transformed $(\log (x+1))$ for variances homogeneity.

\section{Results}

\section{Socio demographic characteristics of respondents}

In total, 500 pigeonpea producing households including 190 in the Guinean zone, 200 in Sudano-Guinean zone and 110 in the Sudanian zone were surveyed. Pigeonpea farmers participated in the surveys were from 21 to 76 years old with an average of $45.9 \pm 9.2$ years old. The majority (62.4\%) of pigoenpea farmers were men (62.4\%) and illiterate (43.4\%), while $31.6 \%$ and $25 \%$ were found to have primary and secondary levels of education, respectively. The average household size was $6.4 \pm 2.1$ members (ranging from 3 to 11 members). The years of experience was $15 \pm 8$ years, on average (Table 2).

Significant differences in surveyed pigeonpea farmers' ages were observed even across ecological zones. On average, farmers in the Guinean zone are older (48.7 years against 44 years) and more experienced than Sudano-Guinean zone farmers (18.4 years of experience against 16.5). The number of farmers with no education, primary and secondary level of education varied between ecological zones. 


\section{Local nomenclature}

Across the thirteen sociolinguistic groups surveyed, 50 different pigonpea local names were recorded in the local dialects. In reference to the various vernacular names identified, the generic name of pigeonpea varied according to sociolinguistic group and ecological zones (Table 3).

In the Guinean and Sudano-Guinean zones, pigeonpea is called Hounkoun, Kloué or Klouékoun referring to cowpea, by farmers belonging to Fon and Mahi sociolinguistic groups while in the Guinean and Sudanian zones, pigeonpea is called, Otili in reference to a pod-producing tree, by farmers belonging to Nago and Dendi sociolinguistic groups. However, Bariba and Peulh sociolinguistic groups designated pigeonpea by Wotiri in reference to a pod-producing erected tree. Moreover, in the Guinean zone, farmers belonging to Holly and Yoruba sociolinguistic groups designated pigeonpea by Otini. Pigeonpea is called Ekloui or Kloui by Adja sociolinguistic group. In Sudano-Guinean zone, pigeonpea is called Colo (meaning is unknown to farmers) by Idaasha sociolinguistic group while pigeonpea is called Tissi Tounan and Itoun by Biali and Somba sociolinguistic groups respectively, referring to cowpea.

\section{Folk taxonomy}

In the study area, farmers were using 5 different criteria to designate pigeonpea. The great majority of names (90.7\%) given to pigeonpea have a meaning. More than half of pigeonpea vernacular names correspond to the morphological aspect (71\%) of seeds. This includes seed coat colour (85.5\%), seed coat and eyes colour (9.2\%), seed size (1.3\%), seed coat colour and size (4\%). Plant type (3.7\%), seed origin (8.4\%), vegetative cycle (10.3\%) and in reference to cowpea (3.7\%) were also among criteria used by farmers to name pigeonpea (Table 4).

The folk taxonomy of pigeonpea has a hierarchical structure with two hierarchy levels as found in several sociolinguistic groups (Adja, Bariba, Fon, Holly, Idaasha, Mahi, Nago, Peuhl and Yorouba). For example, in the Adja sociolinguistic group, the generic name of pigeonpea Ekloui or Kloui is subdivided into 5 infra-specific pigeonpea taxa (Ekloui djou, Ekloui koudji, Ekloui ri, Ekloui wlanwlan, Ekloui wliwlito). In the Fon sociolinguistic group, the generic name of pigeonpea Klouékoun is subdivided into 6 infraspecific pigeonpea taxa (Klouékoun vôvô, Klouékoun wéwé, Klouékoun wéwé tété, Klouékoun wéwé noukoun vôvô, Klouékoun wéwé noukoun wiwi, Klouékoun wlanwlan). While in the Bariba sociolinguistic group, the generic name of pigeonpea Wotiri is subdivided into 4 infra-specific pigeonpea taxa (Wotiri gbika, Wotiri goukorou, Wotiri wonka, Wotiri souan).

\section{Diversity of cultivated pigeonpea landraces}

Based on seed characteristics, fifteen pigeonpea landraces were identified in the study area (Figure 2). At village level, the number of pigeonpea landraces ranged from 1 to 5 with an average of $2.7 \pm 1$. The highest number of landraces (5) per village was reported at Ouèssènè in the department of Alibori. At the household level, the number of pigeonpea landraces held by farmers ranged from 1 to 3 with an average of $1.3 \pm 0.5$. Specifically, $72.2 \%, 27.6 \%$ and $0.2 \%$ of the farmers cultivated 1,2 and 3 landraces respectively. The highest number of landraces (3) per household was reported at Ouèssènè in the department of Alibori and maintained by only one farmer. The Sudano-Guinean zone contained the highest number of landraces followed by the Guinean and Sudanian zones (11,9 and 7 landraces respectively) while the highest number of landraces (5) per village and per household (3) was recorded in the Sudanian zone.

\section{Distribution and extent of pigeonpea landraces}

Within each ecological zone, pigeonpea production was limited to specific districts and departments. In the Guinean zone, the production was restricted to the districts of Adja-Ouèrè, Kétou and Pobè in the department of Plateau, and the districts of Aplahoué, Klouékanmè and Lalo in the department of Couffo. In the Sudano-Guinean zone, pigeonpea is cultivated in the districts of Dassa-Zoumè, Ouèssè, Savalou and Savè in the department of Collines, and the districts of Covè, Djidja, Zakpota and Zangnannado in the department of Zou. Lastly, in the Sudanian zone, pigeonpea is cultivated in the districts of Bembèrèkè and Kalalé in the department of Borgou, and in the district of Gogounou in the department of Alibori. 
The Four Squares Analysis revealed that in the Guinean zone, among the 9 landraces recorded, 1 (Klouékoun wéwé noukoun vôvô (Mahi and Fon sociolinguistic groups)) is cultivated by many households on a large area, 1 (Otili founfoun kékélé (Idaasha sociolinguistic group)) by few households on large area while the 7 remaining ((Ekloui djou (Adja sociolinguistic group), Wlétchivé kloui (Adja sociolinguistic group), Carder ekloui (Adja sociolinguistic group), Otili founfoun lakoun (Idaasha sociolinguistic group), Klouékoun wéwé tété(Mahi sociolinguistic group), Otili kpoukpa (Nago sociolinguistic group) and Klouékoun vôvô (Fon and Mahi sociolinguistic groups)) are produced by few households on a small area.

In the Sudano-Guinean zone, Klouékoun wéwé nounkoun wiwi (Mahi and Fon sociolinguistic groups) is cultivated by many households on a large area, Klouékoun wéwé tété (Mahi sociolinguistic group) and Otili founfoun kékélé(Idaasha sociolinguistic group) are cultivated by few households on a large area, and Wlétchivé kloui (Adja sociolinguistic group) and Klouékoun wlanwlan (Fon sociolinguistic group) by many households on a small area. Klouékoun wéwé nounkoun wiwi (Mahi and Fon sociolinguistic groups), Otini kpoukpa (Holly sociolinguistic group), Colo kpikpa (Idaasha sociolinguistic group), Otili founfoun lakoun (Idaasha sociolinguistic group), Otili kpoukpa (Nago sociolinguistic group) and Klouékoun vôvô (Fon and Mahi sociolinguistic groups) are cultivated by few households on a small area.

In the Sudanian zone, 2 landraces ((Klouékoun wéwé nounkoun wiwi (Mahi and Fon sociolinguistic groups) and Otili founfoun kékélé(Idaasha sociolinguistic group)) are cultivated by many households on a large area while 1 landrace ((Klouékoun wlanwlan (Fon sociolinguistic group)) is cultivated by few households on a large area. 4 landraces ((Ekloui djou (Adja sociolinguistic group), Wotiri wonka (Bariba sociolinguistic group), Wotiri souan (Bariba sociolinguistic group) and Klouékoun vôvô (Fon and Mahi sociolinguistic groups)) are cultivated by few households on a small area. Thus, in the Guinean zone, 7 landraces are under threat of disappearance, 6 in the Sudano-Guinean zone versus 4 in the Sudanian zone. In areas where landraces are threatened, the frequency of disappearance varied between 50 and $100 \%$ (Table 5).

At on-farm level, the landraces distribution analysis revealed that Otini kpoukpa (Holly sociolinguistic group), Colo kpikpa (Idaasha sociolinguistic group) and Klouékoun wéwé nounkoun wiwi (Mahi and Fon sociolinguistic groups) were specific to the Sudano-Guinean zone; Wotiri souan (Bariba sociolinguistic group) and Wotiri wonka (Bariba sociolinguistic group) specific to the Sudanian zone while Carder ekloui (Adja sociolinguistic group) was specific to the Guinean zone. Klouékoun wéwé nounkoun wiwi (Mahi and Fon sociolinguistic groups), Otili founfoun kékélé (Idaasha sociolinguistic group) and Klouékoun vôvô (Fon and Mahi sociolinguistic groups) were cosmopolitan for the three ecological zones. Landraces named Wlétchivé kloui (Adja sociolinguistic group), Otili founfoun lakoun (Idaasha sociolinguistic group), Klouékoun wéwé tété(Mahi sociolinguistic group) and Otili kpoukpa (Nago sociolinguistic group) were present in the Guinean and Sudano-Guinean zones, Ekloui djou (Adja sociolinguistic group) in the Guinean and Sudanian zones while Klouékoun wlanwlan (Fon sociolinguistic group) was present in the Sudano-Guinean and Sudanian zones.

\section{Reasons for pigeonpea production and use category}

Our study has revealed that pigeonpea produced for three main reasons depending on the ecological zones (Table 6). In the Guinean and Sudano-Guinean zones, nutritional value is the main motivation while in the Sudanian zone, the land fertilizing power is the main motivation. The third reason is the market value.

The different pigeonpea use categories were mainly concentrated on grains. Based on their fidelity level, pigeonpea is used more in medicine in the Guinean ( $F L=19.5 \%$ ) and Sudanian ( $F L=23.9 \%$ ) zones. According to famers, boiled leaves are administered orally to treat malaria. Also, the decoction of the leaves is used in baths to treat measles and is also used as an antibiotic to treat mouth sores or tooth decay. The roots, when chewed, prevents the rise of snake venom, in the case of snake bite.

The use of pigeonpea grains as an offering for food or symbolic purposes and in sacrifice to divinity to request for more yield the following season is specific to the Sudano-Guinean zone and only restricted to Holly and Nago sociolinguistic groups. While grain processing into donuts is specific to Guinean ( $\mathrm{FL}=4.3 \%$ ) and Sudano-Guinean ( $\mathrm{FL}=2 \%$ ) zones and only restricted to Holly and Adja sociolinguistic groups. In these zones, pigeonpeas are roasted and ground to flour to sprinkle in sauces as a nutritional supplement by farmers belonging to Holly sociolinguistic group or to make donuts by farmers belonging to Adja sociolinguistic group. Consumption, weeds control and land fertilization are common to all three ecological zones (Table 6).

Page $7 / 31$ 


\section{Cultural practices}

Pigeonpea was considered as an annual plant by most of the surveyed farmers (93.2\%). Only $6.2 \%$ of farmers considered this legume as a perennial plant. For the latter, the plant is left in the fields and is harvested the following year. The main pigeonpea farming activities included: ploughing, sowing, weeds control, pod harvest, pod plugging and winnowing. Seeding and weeds control were practiced by all the farmers. Pigeonpea is sown between April and June (73.6\%) by intercropping with other seasonal crops $(82.8 \%)$ or in pure stand $(17.2 \%)$. Three sources of labour were observed. For farming activities, $13.2 \%$ of farmers used family labour, $73 \%$ combined family and friends labour while $13.8 \%$ used a combination of family, friends and jobber labour (Table 7).

The activity of land fertilization was never practiced by farmers included in this study while only $14 \%$ of farmers included in this study used pesticide. The average grain yield in farmers' fields was estimated at $553.4 \pm 36.3 \mathrm{~kg} / \mathrm{ha}$. According to the farmers, during the three last years, Sudano-Guinean zone was the largest cropping area followed by the Guinean zone while farmers in the Sudanian zone produced pigeonpea on a small cropping area (Table 7). Sowing was actively done between April - June in the Guinean and Sudano-Guinean zones ( $97.9 \%$ and $91 \%$ respectively) whereas it was actively done in June, July and August in the Sudanian zone (68.2\%). Intercropping with other seasonal crops such as maize and millet was specific to the Guinean (100\%) and Sudano-Guinean (98.5\%) zones while pigeonpea was cultivated mostly in pure stand in the Sudanian zone (75.4\%).

Family and friends were the main source of labour for various farming activities in the Guinean and Sudano-Guinean zones ( $87.9 \%$ and $61.5 \%$ respectively) while family members $(49.3 \%)$ were the main source of labour in the Sudanian zone. Our results revealed that the average yield of pigeonpea in the Sudanian zone is lower $(522.3 \pm 44 \mathrm{~kg} / \mathrm{ha})$ than that of the Guinean and Sudano-Guinean zones ( $557.5 \pm 15.9 \mathrm{~kg} / \mathrm{ha}$ and $566.6 \pm 35.8 \mathrm{~kg} / \mathrm{ha}$ respectively).

\section{Seed system}

Different sources of seeds were mentioned by farmers. Previous harvest $(60.2 \%)$ is the main source of seeds. Other sources are borrowing of seeds from friends (22\%) and seeds purchased from the local market (17.8\%). After each harvest, $67.8 \%$ of farmers stored seeds until scarcity at market or for the following season while $32.2 \%$ of them sold seeds in local markets. The comparison of the seed systems between ecological zones revealed that previous harvest is the main source of seeds in the Guinean and Sudano-Guinean zones (70\% and $62.9 \%$ respectively) and borrowing of seeds from friends is the main source (50.4\%) in the Sudanian zone. After each harvest, farmers stored more grains in the Guinean and Sudano-Guinean zones (70\% and $84 \%$ respectively) while more grain was immediately sold in the Sudanian zone (65.5\%) (Table 7).

\section{Pigeonpea production constraints}

In total, 10 constraints were identified as major bottleneck in pigeonpea production. Among which, the long vegetative cycle, pests, diseases and rainfall irregularity were considered as the major constraints (Table 8). According to the farmers' descriptions, low productivity ranked seventh among the constraints followed by the sensitivity to storage insects. All these constraints have been reported in the three ecological zones. However, their relative importance varied from one zone to another. The most important constraint in the Guinean and Sudano-Guinean zones was the long vegetative cycle. Sensitivity to pests and diseases ranked second. In the Sudanian zone, pests and diseases ranked as the most important constraint and soil poverty was second (Table 8).

\section{Incidence of pests on pigeonpea yield and control methods}

The incidence of pests and diseases on farmers' field was as follows: low in the Guinean and Sudano-Guinean zones (52.6\% and $42.5 \%$ respectively), high in the Sudanian zone (81.8\%) (Table 9). As a result, farmers reported growth retardation and damage to flowers or pods respectively. A pest control method was only reported in the Sudanian zone (63.7\%). Three reasons justified the non-control of pests: high price of pesticides (49.6\%), risk of intoxication (29.6\%) and lack of sprayers (20.8\%).

\section{Evolution of pigeonpea production in Benin}


Overall, majority of the farmers (69.4\%) reported a decrease of pigeonpea production in Benin. This downward trend was observed for the Guinean and Sudano-Guinean zones (75.79\% and $85.5 \%$ respectively). In these zones, the decrease in cropping area is highly significant $(\mathrm{p} \otimes 0.001)$. The average cropping area was $0.9 \pm 0.2$ ha in $2015,0.8 \pm 0.1$ ha in 2016 and $0.5 \pm 0.1$ ha in 2017 in the Guinean zone (Table 7). Similarly, in the Sudano-Guinean zone, average cropping area was $1.3 \pm 0.8$ ha in $2015,0.9 \pm$ 0.4 ha in $2016,0.7 \pm 0.3$ ha in 2017 (Table 7). In contrast, in the Sudanian zone, pigeonpea cultivation is increasing (70.91\%). In this zone, the increase of cropping area is highly significant ( $\mathrm{p} \otimes 0.001)$. The average cropping area was $0.3 \pm 0.1$ ha in $2015,0.4 \pm$ 0.1 ha in 2016 and $0.4 \pm 0.1$ ha in 2017 (Table 7). This increase is due to the fertilizing power of the plant (89.1\%) and weed control (10.9\%).

\section{Farmers' preference criteria of pigeonpea}

Throughout the study, 11 criteria depending on the ecological zones and different sociolinguistic groups highlighted the choice of pigeonpea varieties to be cultivated by farmers. Farmers perceived precocity, resistance to pests and diseases, short cooking time, adaptability to any type of soil, good taste, and high productivity as the most important preferred traits (Table 10). In the Guinean and Sudano-Guinean zones farmers had a strong preference for early maturing (precocity) and resistant to pests and diseases pigeonpea varieties; while in the Sudanian zone, farmers preferred pigeonpea varieties that were resistant to pests and diseases and adaptable to any type of soil (Table 10). Precocity appeared high on the list of criteria for all sociolinguistic groups except Nago sociolinguistic group for whom adaptability to any type of soil was the first criterion. Farmers belonging to the Bariba sociolinguistic group preferred varieties that mature early, are resistant to pests and diseases, have short a cooking time, show adaptability to any type of soil and have good taste (Table 11). In addition to Bariba sociolinguistic group's preferred traits, farmers belonging to Boo sociolinguistic group showed strong tendency towards pigeonpea varieties that are cultivable at any time of the year and resistant to storage insects. Dendi sociolinguistic group preferred varieties with high productivity and cultivable at any time of the year and Peuhl sociolinguistic group preferred highly productive and resistant to storage insects pigeonpea varieties. Precocity, resistance to pests and diseases, short cooking time and adaptability to any type of soil were farmers belonging to the Yoruba sociolinguistic group preferred traits.

\section{Participatory evaluation of pigeonpea landrace grown in Benin}

Our results revealed that none of the landraces identified simultaneously in the three ecological zones is performing for a given character simultaneously in the three ecological zones (Table 12). Moreover, no landrace is performing simultaneously for all 5 evaluated traits. Nevertheless, Carder ekloui (Adja sociolinguistic group) specific to the Guinean zone combined 4 good performances (high productivity, short cooking time, resistance to pests and diseases, and resistance to storage insects). Carder ekloui (Adja sociolinguistic group) and Otili founfoun kékélé(Idaasha sociolinguistic group) showed high productivity in the Guinean and Sudano-Guinean zones but showed low productivity in the Sudanian zone however, these two landraces, showed resistance to pests and diseases. Klouékoun vôvô (Fon and Mahi sociolinguistic groups) showed high productivity, short cooking time, resistance to pests and diseases, resistance to storage insects and short vegetative cycle in the Guinean and SudanoGuinean zone, but showed low productivity and susceptibility to pests and diseases in the Sudanian zone (Table 12).

\section{Discussion}

Our study showed that pigeonpea generic names varied according to sociolinguistic group and ecological zones. Our findings are similar to Ayenan et al. [9] and Zavinon et al. [11] in Southern Benin. However, pigeonpea is designated by the same generic name by farmers belonging to different sociolinguistic groups in the same ecological zone or different ecological zones. This convergence in generic names within different sociolinguistic groups could be explained by the fact that these groups could have common origins or cohabitation could have facilitated the transfer of knowledge over time.

In addition, based on the meaning of generic names, famers across the sociolinguistic groups within three ecological zones recognized pigeonpea by referring to it as cowpea. This suggests that famers do not have a good knowledge of the botanical systematic of pigeonpea. There is therefore no link between folk taxonomy and the scientific classification of pigeonpea. Since there could be a connection between folk taxonomy and scientific classification of the species [37], our findings are contrary to Akohoué et al. [14] on Kersting's groundnut in Benin. However, the hierarchical characterization of pigeonpea folk taxonomy was 
like the observation made by Loko et al. [38] on common beans and reflects the high diversity level of pigeonpea in the surveyed sociolinguistic groups.

Our results from Adja sociolinguistic group infra-specific pigeonpea taxa was contrary to that of Ayenan et al. [9] and Zavinon et al. [11] who distinguished respectively 2 and 3 infra-specific pigeonpea taxa. However, local names do not necessarily reflect the genetic history of landraces because different names may be given to identical seeds of landraces or a single name may apply to heterogeneous crops [39]. This situation may contribute to under or over-estimation of the diversity within species [40, 25, 41, 9]. To avoid redundancies and optimize the efficient conservation and sustainable use of pigeonpea diversity, it is important to conduct morphological and molecular characterizations to avoid redundancies and establish equivalence between the local names $[28,42,43]$.

Farmers used the morphological aspect of seeds (coat colour, seed eye colour, and seed size), plant type, seeds origin and vegetative cycle for folk varieties' identification. These criteria of pigeonpea classification and identification are among the descriptors of $C$. cajan recommended by International Board for Plant Genetic Resources (IBPGR) and International Crops Research Institute for the Semi-Arid Tropics (ICRISAT) [44] and used by many authors in morphological characterization of this legume. Our study revealed that the morphological aspect of seeds (particularly the seed coat colour) was the predominant criterion used by the farmers to classify and identify pigeonpea landraces. The main reason is that seed coat colour is unique to each landrace while other traits may be commonly shared [14]. However, our findings were contrary to Manyasa et al. [45] who reported pigeonpea seed size and maturity as the most important criteria used by the famers in Ugandan. Although, similar observations were reported by Esan and Ojemola [46] in Nigeria, Ayenan et al. [9] and Zavinon et al. [11] in Southern and Central Benin and suggests that selection based on the morphological aspect of seeds will have a definite role in the framework of onfarm conservation of this legume in Benin.

According to Ayenan et al. [9] and Zavinon et al. [11], eight and seven pigeonpea landraces respectively were recorded in Benin. In our study, we recorded fifteen pigeonpea landraces based on seed characteristics. The seven new landraces are the blackish seeded landrace called Otini kpoukpa (Holly sociolinguistic group), the brown seeded landrace called Colo kpikpa (Idaasha sociolinguistic group), the cream with black eye seeded landrace called Klouékoun wéwé nounkoun wiwi (Mahi and Fon sociolinguistic groups), the cream seeded landrace called Klouékoun wéwé tété(Mahi sociolinguistic group), the light red seeded landrace called Otili kpoukpa (Nago sociolinguistic group), the purple and mottled seeded landrace called Wotiri wonka (Bariba sociolinguistic group) and the red and mottled seeded landrace called Wotiri souan (Bariba sociolinguistic group). Considering that previous studies did not take into account the entire production area, though seemingly insignificant, a part of the existing pigeonpea landraces in Benin was left out. This finding suggests that the extent of the area studied affects species richness [47, 14]. Thus, a study which aims to reflect the existing diversity of cultivated species should not be restricted to only the major production areas of the species.

Our results revealed that pigeonpea diversity at on-farm level was specific to ecological zones. In fact, each landrace didn't have the same distribution and extent across ecological zones. For instance, Otili founfoun kékélé (Idaasha sociolinguistic group) was cultivated by a few households on a large areas in the Guinean and Sudanian-Guinean zones while it was cultivated by many households on a large area in the Sudanian Zone. This practice involves an indirect selection of some landraces in certain ecological zones while it promotes a gradual disappearance of another. Therefore, conservation strategies should be defined for landraces under threat of disappearance according to their ecological zones. Thus, each ecological zone could be a favorable candidate for in-situ conservation of pigeonpea genetic resources in Benin. The highest number of landraces per village and per household was recorded at Ouèssènè in the department of Alibori in the Sudanian zone. Therefore, the Sudanian zone is essential in the conservation of pigeonpea genetic resources in Benin and confirms that each ecological zone could be a favorable candidate for in-situ conservation of pigeonpea genetic resources as suggested previously.

It did not come as a surprise that the fertilizing power of pigeonpea was recorded as a major reason for producing this legume, because pigeonpea has a significant position in dry land farming systems. This is especially adopted by small and marginal farmers in many parts of the world by fixing nitrogen and flexibility for mixed cropping or inter crop [48, 49]. The use of pigeonpea leaves to treat various diseases such as malaria corroborates the observations made by Ayenan et al. [9] and Zavinon et al. [11] in Benin and those of Aiyeloja and Bello [50] and Oladunmoye et al. [51] in Nigeria. Also, the use of pigeonpea as weed control 
has been reported by several authors in Benin $[52,53,5]$. Nonetheless, pigeonpea root utilization in prevention of snake venom rising and grain processing into donuts has not been reported by previous studies.

Unfortunately, this technological ability of pigeonpea grains is weakened by its oil retention. Thus, this technological ability of pigeonpea grains must be explored and improved, like the soybean's transformation into cheese, in Benin. This will reduce malnutrition in rural populations and could contribute to the in-situ conservation of the existing pigeonpea diversity. Moreover, the use of pigeonpea grains as an offering for food or for symbolic purposes and in sacrifice to divinity has not yet been reported by previous research. All these findings are dependent on sociolinguistic groups and ecological zones and suggest that pigeonpea farmers in Benin do not have the same knowledge of pigeonpea uses. However, as a result of vertical knowledge transmission $[54,14]$, specific knowledge relative to the plant part uses might be kept and transmitted within communities in some areas. With the knowledge that integrating cultural practices of local communities leads to an efficient on-farm conservation [55, 38], this specific use category of pigeonpea genetic resource shows the potential of the cultural approach for the conservation of this legume in Benin.

Our study revealed that in the Sudanian zone, pigeonpea cultivation is increasing while it is decreasing in the Guinean and Sudano-Guinean zones. Our results in the Guinean and Sudano-Guinean zones corroborate Zavinon et al. [11]. In fact, the productivity of the smallholder farming system in the Sudanian zone is under threat due to soil fertility decline [56]. Research in many parts of Africa including Benin have shown that legumes have the potential to sustain soil fertility in smallholder farming systems $[57,58,49]$. Consequently, thanks to the Protection and Rehabilitation of Soils to Improve Food Security project of the German Federal Ministry for Economic Cooperation and Development, an integrated soil fertility management through maximum use of different organic sources of fertilizers such as pigeonpea, was initiated in 2015. This project allowed, in the Sudanian zone, the popularization of pigeonpea by using its fertilizing power and supports the vital role of the Sudanian zone for the in-situ conservation of pigeonpea genetic resources in Benin.

As reported by Ayenan et al. [10] and Zavinon et al. [12], our study showed that pigeonpea seed system in Benin is informal. Similar results were achieved in Tanzania [59] and in India [15]. This informal seed system has the advantage of facilitating seed exchanges among farmers and villages [16]. Nevertheless, marketed seeds deserve some attention taking into consideration that seed acquisition from the market does not guarantee genetic purity [60]. It is extremely important to have good quality seeds available to farmers, in order to increase pigeonpea productivity $[60,10]$. At on-farm level, the intercropping system of pigeonpea with other crops has been found in other countries such as Uganda [45] and Kenya [61]. Accordingly, after each harvest, majority of farmers stored seeds until scarcity at market before selling them. On the contrary, farmers in the Sudanian zone sold their seeds immediately to address urgent financial burdens such as educating their children. As a result, pigeonpea is an essential source of household income and reduces poverty in Benin as reported by Dansi et al. [5].

In Benin, there are many factors negatively affecting pigeonpea production. Long vegetative cycle and pests and diseases were the main constraints affecting pigeonpea production. Indeed, african pigeonpea is characterized by its late maturity $[62,12]$. According to farmers, these genotype cultivation as a sole crop occupies land which could be used for other crops. Our results were in accordance with Ayenan et al. [10] and Zavinon et al. [12] who showed the lack of improved varieties (long vegetative cycle, low productivity, insect attack and lack of quality seed) as the main constraint affecting pigeonpea production in the Guinean and Sudano-Guinean zones of Benin. Moreover, the occurrence of pests and diseases as the top constraint in the Sudanian zone is hardly surprising. In this zone, pigeonpea was cultivated mostly on pure land which facilitates pests' attraction. Our results confirmed the observation made by Sarkar et al. [49] that intercropping system minimizes pests and diseases attraction compared to the pure stand system. Farmers in this zone had limited access to pesticides and were suffering the most from production loss. Although the impact of pests and diseases was found to be low in the study area, their presence is a key indicator of the urgent need to develop strategies against these pests. Instead of the use of pesticides, an integrated pests management system is recommended, through the combination of biological control based on use of natural enemies of these pests and genetic control based on use of tolerant or resistant varieties [63, 64, 29].

As is the case with various legumes where storage insects are the major constraint [65], surveyed farmers reported seeds' attack by storage insects. Farmers reported the use of toxic products to protect their seeds. Thus, an education of farmers or consumers for a purely biological conservation, such as the use of small peppers, is highly recommended, as in the case of Kersting's 
groundnut [66]. Curiously, low productivity ranked seventh among the constraints and suggests that low productivity represents only a small portion of the constraints relative to pigeonpea production and could be the direct consequence of the negative effects of other constraints [61]. Therefore, the lack of improved varieties appears as a challenge to pigeonpea production. Hence, the availability of improved varieties and their distribution across the different ecological zones according to their specific needs can alleviate pigeonpea production constraints in Benin. The government should encourage small-scale enterprises to provide farmers with improved seeds.

A farmers' preference criteria plays an important role in breeding programs and facilitates the adoption of improved varieties [40, 11]. Our study revealed that famers perceived precocity, resistance to pests and diseases, good taste, and short cooking time as the most important preferred traits. Similar observations on pigeonpea were made by Mergeai et al. [61] in Kenya, Shiferaw et al. [67] in Tanzania, Changaya [68] in Malawi, Ogbe and Bamidele [69] in Nigeria and Ayenan et al. [10] in Southern Benin. All these criteria were correlated with identified constraints. This suggests a veritable link between these two parameters as reported by Odjo et al. [70] on rice genetic resources in Benin. The precocity as criterion is important for famers because short vegetative cycle varieties should certainly encourage them to produce pigeonpea. In the global climate context where changes are noticeable, early varieties will provide producers the guarantee that pigeonpea plants attain a significant level of vegetative development before the rain cuts. The high productivity as criterion of varietal choice is not unexpected as it is the most desired criterion for any breeder and farmer [71, 30].

Our result was contrary to Zavinon et al. [11] who found high market value to be the famers' main preference criterion. In fact, the high market value cannot appear as the first preference criteria, because this criterion could only be the result of the adoption of an improved variety for one of the other criteria. Our study also revealed that preference criteria varied across different sociolinguistic groups, however, convergence in preference criteria between certain sociolinguistic groups was observed. This could be explained by the cultural links and the intensive knowledge exchange between these sociolinguistic groups or due to the common origin of the groups.

For a given character, a landrace does not show the same performance across the different ecological zones. For instance, the landrace called Otili founfoun kékélé (Idaasha sociolinguistic group) perceived by farmers as having high productivity in the Guinean and Sudano-Guinean zones showed low productivity in the Sudanian zone. This may be due to the variability in soil types, fertility and organic matter turn over, soil nutrient dynamics [72], and water regime [73] across ecological zones. In addition, the landrace called Klouékoun vôvô (Fon and Mahi sociolinguistic groups) showed high productivity in the Guinean and SudanoGuinean zones but low productivity in the Sudanian zone. Thus, as mentioned, variability in soil types, fertility and organic matter turn over, soil nutrient dynamics or water regime justify these agronomical differences.

Carder ekloui (Adja sociolinguistic group) only identified in the Guinean zone must deserve attention. The cultivar combined four good performances - high productivity, short cooking time, resistance to pests and diseases, resistance to storage insects according to famers. Carder ekloui seems to be a promising cultivar which unfortunately faces threat of disappearance. There is urgent need to process to ex-situ as well in-situ conservation to preserve this cultivar and all those under threat. All identified cultivars in the current study must be tested to verify the performances stated by the farmers. Consequently, morphological and molecular characterizations are highly recommended to select suitable cultivars for breeding programmes. Thereafter, association mapping of candidates' genes/QTLs for desirables traits can be done and used in future marker-assisted breeding programmes. Breeding of adapted pigeonpea resistant to pests and diseases and adaptable to any type of soil will be of dual benefit to famers in the Sudanian zone. It will enhance pigeonpea's chain value and will also restore the fertilizing power of impoverished lands. Considering farmers' preference criteria, the performing cultivars identified can be used in varietal exchange programmes to enhance pigeonpea production in Benin.

\section{Conclusions}

Our study showed a diverse variety of pigeonpeas with a total of fifteen landraces identified based on seed characteristics. Seven new landraces were found and a number of them were specific to an agro-ecological zone. A highly significant decrease in cropping areas was observed in the Guinean and Sudano-Guinean zones. Several factors including pests and diseases and long vegetative cycle constrain pigeonpea production. The absence of a performing seed system was also observed. Through

Page $12 / 31$ 
participatory evaluation, this study revealed the existence of a few performing cultivars and cultivars under threat of disappearance. The establishment of an effective seed system and the definition of efficient pest management strategies, breeding or introducing varieties based on farmers' preference criteria could increase pigeonpea production in Benin. A few of the performing cultivars identified in the study can be used to mitigate the effects of identified constraints in varietal exchange programs. Morphological and molecular characterizations of identified cultivars are highly recommended to select suitable cultivars for breeding programs. In-situ and ex-situ conservation strategies and preservation of traditional knowledge associated to pigeonpea are essential to preserve landraces threatened to disappear and to conserve pigeonpea diversity in Benin.

\section{Declarations}

\section{Funding}

Not applicable.

\section{Acknowledgments}

We thank the anonymous reviewers for their comments on previous versions of the manuscript. We express our sincere gratitude to all farmers, village chiefs, and leaders of farmer groups for their contributions to the success of this study. We would like to acknowledge the technical support of Falil BANI OROU KOUMA during the prospection and collection of cultivars. We express our sincere gratitude to the Doctors Ruth TAMADAHO, Aliu IBUKUN, Rachit Kumar SAXENA and Rajeev Kumar VARSHNEY for correcting english language errors.

\section{Availability of data and materials}

Raw and treated data generated during the study are available from the corresponding authors on reasonable request.

\section{Authors' contributions}

GK designed the study, collected and analyzed data and drafted the manuscript. AGF participated in the interviews. GD, LEYL, AD, $C A$ and $A D$ supervised data analysis and revised the manuscript. All authors read and approved the final manuscript.

\section{Consent for publication}

Not applicable.

\section{Competing interests}

The authors declare that they have no competing interests.

\section{Ethics approval and consent to participate}

Not applicable.

\section{Abbreviations}

p: $p$ value

INSAE: Institut National de la Statistique et de l'Analyse Economique

\section{References}

1. Chanda Venkata SK, Nadigatla Veera Prabha Rama GR, Saxena RK, et al. Pigeonpea improvement: An amalgam of breeding and genomic research. Plant Breed. 2018; 00:1-10. 
2. Singh L, Gupta SC and Faris DG. Pigeonpea breeding. In: Nene YL, Hall SD and Sheila VK, editors. The pigeonpea: CAB International, Cambridge, UK; 1990; p. 375-420.

3. Choudhary H, Singh S, Parvez N, RathoreR, Singh RP. Performance of farmers pigeon pea [cajanus cajan L. Millsp.] varieties: opportunities for sustained productivity and dissemination of varieties. Int J Agric Sci. 2016; 8(61):3471-3474.

4. Saxena RK, Saxena KB and Varshney RK. Application of SSR markers for molecular characterization of hybrid parents and purity assessment of ICPH 2438 hybrid of pigeonpea [Cajanus cajan (L.) Millsp.]. Mol. Breed. 2010; 26:371-380.

5. Dansi A, Vodouhe R, Azokpota P, Yedomonhan H, Assogba P, Adjatin A, Loko YL, Dossou-Aminon I, Akpagana K. Diversity of the neglected and underutilized crop species of importance in Benin. Sci World J. 2012; Article ID 932947.

6. Versteeg MN, Koudokpon V. Participative farmer testing of four low external input technologies, to address soil fertility decline in Mono province (Benin). Agr syst. 1993; 42(3):265-276.

7. Aihou K. Interaction between organic input by Cajanus cajan (L.) Millsp. and inorganic fertilization to maize in the derived savanna of the Benin Republic. PhD Thesis, Wageningen University; 2003.

8. Ministère de l'Agriculture de l'Elevage et de la Pêche (MAEP)/Direction de la Programmation et de la Prospective (DPP). Statistique de production du pois d'Angole: Annuaire statistique. Bénin; 2017.

9. Ayenan MAT, Danquah A, Ahoton EL, Ofori K. Utilization and farmers' knowledge on pigeon pea diversity in Benin, West Africa. J Ethnobiol Ethnomed. 2017a;13:37.

10. Ayenan MAT, Ofori K, Ahoton LE, Danquah A. Pigeonpea [(Cajanus cajan (L.) Millsp.)] production system, farmers' preferred traits and implications for variety development and introduction in Benin. Agric. Food Secur. 2017b; 6:48.

11. Zavinon F, Adoukonou-Sagbadja H, Ahoton L, Vodouhê R, Ahanhanzo C. Quantitative Analysis, Distribution and traditional management of pigeon pea [Cajanus cajan (L.) Millsp.] Landraces' diversity in Southern Benin. Eur Sci J. 2018; 14(9):184211.

12. Zavinon and Sagbadja. Pigeon pea [Cajanus cajan (L.) Millsp] cultivation, its major constraints and ethnobotanical status in Southern Benin J Agric Crop Res. 2019; 7(6):95-105.

13. Institute for Advanced Sustainability Studies (IASS). Gestion Durable des Terres : Analyse d'expériences de projets de développement agricole au Bénin. Assogba SCG, Akpinfa E, Gouwakinnou G, Stiem L (ed.) Potsdam, Février 2017.

14. Akohoué F, Sibiya J, Achigan-Dako EG. On-farm practices, mapping, and uses of genetic resources of Kersting's groundnut [Macrotyloma geocarpum (Harms) Maréchal et Baudet] across ecological zones in Benin and Togo. Genet Resour Crop Evol. 2019; 66:195-214.

15. Mula MG, Kumar CVS, Mula RP. Seed system: the key for a sustainable pulse agriculture for smallholder farmers in the dry land tropics 1. In: 23rd PHILARM national convention. Naga City, Camarines Sur, Philippines; 2013.

16. Mula MG. Seed system institutionalization for pulses: a must in the Philippines. In:1st Philippine Pigeonpea Congress. Batac, llocos Norte, Philippines: Mariano Marcos State University (MMSU). 2014; 16-18 December.

17. Berlin B. Folk systematics in relation to biological classification and nomenclature. Annu Rev Eco Evol Syst. 1973; 4:25971.).

18. Zent EL, Zent S, Iturriaga T. Knowledge and use of fungi by a mycophilic society of the Venezuelan Amazon. Econ Bot. 2004; 58:214-26.

19. Mekbib F. Infra-specific folk taxonomy in sorghum (Sorghum bicolor (L.) Moench) in Ethiopia: folk nomenclature, classification, and criteria. J Ethnobiol Ethnomed. 2007; 3:38.

20. Dias GB, Gomes VM, Moraes TM, Zottich UP, Rabel GR, Carvalho AO, Moulin M, Goncalves LS, Rodrigues R, Da Cunha M. Characterizationof Capsicum species using anatomical and molecular data. Genet Mol Res. 2013; 12:6488-6501.

21. Orobiyi A, Dansi M, Assogba P, Loko LY, Vodouhe R, Akouegninou A, Sanni A. Chili (Capsicum annuum L.) in southern Benin: production constraints, varietal diversity, preference criteria and participatory evaluation. Int Res J Agr Sci Soil Sci. 2013;3(4):107-120.

22. Ntare BR, Ndjeunga J, Waliyar F, Kodio O, Echekwu C A, Kapran I, Da Sylva A, Diallo AT, Amadou A, Bissala HY and Sako K. Farmer Participatory Evaluation and Dissemination of Improved Groundnut Varieties in West Africa. International Crops Research Institute for the Semi-Arid Tropics; 2007 p. 33.

Page 14/31 
23. INSAE. Troisième Recensement Général de la Population et de l'Habitation. Quelques résultats. Institut national de la statistique et de l'analyse économique, Cotonou; 2003. p. 9.

24. Adinci KJ, Akpo Y, Adoligbe C, Adehan SB, Yessinou RE, Sodé Al, Mensah GA, Youssao AKI, Sinsin B, Farougou S. Preliminary study on the tick population of Benin wildlife at the moment of its invasion by the Rhipicephalus microplus tick (Canestrini, 1888). Vet World. 2018;11(6):845-851.

25. Akoègninou A, van der Burg WJ, van der Maesen LJG. Flore analytique de Bénin. Leiden: Backhuys Publishers; 2006.

26. Dansi A, Adoukonou-Sagbadja H, Vodouhe R. Diversity, conservation and related wild species of Fonio millet (Digitaria spp.) in the northwest of Benin. Genet Resour Crop Evol. 2010; 57:827-839.

27. Loko YL, Adjatin A, Dansi A, Vodouhé R, Sanni A. Participatory evaluation of Guinea yam (Dioscorea cayenensis Lam.-D. rotundata Poir. complex) landraces from Benin and agro-morphological characterization of cultivars tolerant to drought, high soil moisture and chips storagee insects. Genet Resour Crop Evol. 2015;62:1181-92.

28. Brush SB. Genes in the Field: on-Farm Conservation of Crop Diversity. Lewis Publishers: Boca Raton. 2000; 3-26.

29. Gbaguidi AA, Dansi A, Loko LY, Sanni A. Diversity and agronomic performances of the cowpea (Vigna unguiculata Walp.) landraces in Southern Benin. Int Res J Agric Sci Soil Sci. 2013;3(4):121-133.

30. Loko YL, Dansi A, Linsoussi C, Tamo M, Vodouhè R, Akoegninou A, Sanni A. Current status and spatial analysis of Guinea yam (Dioscorea cayenensis Lam. -D. rotundata Poir. complex) diversity in Benin. Int Res J Agricult Sci Soil Sci. 2013;3(7):219238.

31. Dansi A, Dantsey-Barry H, Agre AP, Dossou-Aminon I, Assogba P, Loko YL, N'Kpenu EK, Kombaté K, Dansi M, Vodouhè R. Production constraints and farmers' cultivar preference criteria of cultivated yams (Dioscorea cayenensis - D. rotundata complex) in Togo. IJABPT. 2013;4(2):191-199.

32. Christinck KVB, Kshirsagar WE, Bramel-Cox PJ.Participatory methods for collecting germplasm: experiences with famers of Rajasthan, India. Plant Genet Resour Newsletter. 2000; 121:1-9.

33. Mohammed M, Sowley E, Dakora F. Variations in N2 fixation of field-grown Kersting's groundnut (Macrotyloma geocarpum) landraces in response to inoculation with two Bradyrhizobium strains in the northern region of Ghana. S Afr J Bot. 2016; 100(103):333.

34. Gausset, Q. Ranking local tree needs and priorities through an interdisciplinary action research approach. J Transdiscipl Environ Stud. 2004;3(1):1-17.

35. Hoffman B, Gallaher T. Importance indices in ethnobotany. ERA. 2007; 5:201-218.

36. Friedman J, Yaniv Z, Dafni A, Palewitch D. A preliminary classification of the healing potential of medicinal plants, based on a rational analysis of an ethnopharmacological field survey among Bedouins in the Negev Desert, Israel. J Ethnopharmacol. 1986; 16:275-287.

37. Whaanga H, Papa W, Wehi P, Roa T. The use of the Maori language in species nomenclature. JMIC. 2013; 2:78-84.

38. Loko LEY, Orobiyi A, Adjatin A, Akpo J, Toffa J, Djedatin G and Dansi A (2018). Morphological characterization of common bean (Phaseolus vulgaris L.) landraces of Central region of Benin Republic. J Plant Breed Crop Sci. 2018;10(11):304-318.

39. Van Heerwaarden J, Hellin J, Visser RF, et al. Estimating maize genetic erosion in modernized smallholder agriculture. Theor Appl Genet. 2009;119(5):875-888.

40. Adoukonou-Sagbadja H, Dansi A, Vodouhè R, Akpagana K. Indigenous knowledge and traditional conservation of fonio millet (Digitaria exilis, Digitaria iburua) in Togo. Biodivers Conserv. 2006; 15:2379-2395.

41. Kamau JI, Labeyrie V, Njoroge GN, Wanjoya AK, Wambugu PW, Muthamia ZK, Leclerc C. Dealing with farmers' Ethnolinguistic differences when collecting crop diversity on-farm. Plant Genet Resour. 2017;15(5):400-408.

42. Mudaraddi B, Saxena KB. Molecular diversity based heterotic groups in pigeonpea [Cajanus cajan (L.) Millsp.]. Indian J Genet Plant Breed. 2015; 75:57.

43. Bareke T, Asfaw Z, Woldu Z, Beth M, Amssalu B. Diversity of common bean (Phaseolus vulgaris L., Fabaceae) landraces in parts of southern and eastern Ethiopia. Adv Plants Agric Res. 2018;8(6):449-457.

44. International Board for Plant Genetic Resources (IBPGR) and International Crops Research Institute for the Semi-Arid Tropics (ICRISAT). Rome, Italy and Patancheru, India. Descriptors for Pigeonpea (Cajanus cajan (L.) Millsp.); 1993.

Page 15/31 
45. Manyasa EO, Silim SN, Christiansen JL. Variability patterns in Ugandan pigeonpea landraces. J SAT Agric Res. 2009; 7:1-9.

46. Esan and Ojemola. Evaluation of Production Systems, Traditional Knowledge of Pigeon Pea (Cajanus cajan) and Risks of Extinction of Pigeon Pea, Jack Bean (Canavalia ensiformis) and Lubia Bean (Lablab purpureus) in Some Parts of South West Nigeria. JEAI. 2018; 21(4):1-11.

47. Waide RB, Willig MR, Steiner CF, Mittelbach G, Gough L, Dodson SI, Juday GP, and Parmenter R. The relationship between productivity and species richness. Annu Rev Ecol Syst. 1999; 30:257-300.

48. Pandit SR, Sharma A, Patil DH and Dodamani BM. Performance of pigeon pea under different sources of nutrients in rainfed conditions of Karnataka. J Food Legumes. 2015;28(2):43-45.

49. Sarkar S, Panda S, Yadav K, Kandasamy P. Pigeon pea (Cajanus cajan) an important food legume in Indian scenario-A review. Legume Res. 2018; 402:1-10.

50. Aiyéloja AA, Bello OA. Ethnobotanical potentials of common herbs in Nigeria: A case study of Enugu state. Educ Res Rev. $2006 ; 1: 16-22$.

51. Oladunmoye MK, Kehinde FY. Ethnobotanical survey of medicinal plants used in treating viral infections among Yoruba tribe of South Western Nigeria. African J Microbiol Res. 2011; 5:2991-3004.

52. Atachi P, Dannon EA and Rurema DG. Trap cropping and intercropping of pigeonpea (Cajanus cajan L. Millsp.) in pest management of cowpea (Vigna unguiculata L. Walp.) in Southern Benin: competing risk and pest status in pod attack. Ann Sci Agron. 2009a; 9(1):1-20.

53. Atachi P, Dannon EA and Rurema DG. Seed-damaging field pests in an intercropping of pigeonpea (Cajanus cajan L. Millsp.) and cowpea (Vigna unguiculata L. Walp.) in Southern Benin: dynamics of seed attack. Ann Sci Agron. 2009b; 8(2):197-218.

54. Leclerc C, Geo Coppens d'Eeckenbrugge. Social Organization of Crop Genetic Diversity. The G $\times$ E $\times$ S Interaction Model. Divers. 2012;4(1)1-32.

55. O'Neill AR, Badola HK, Dhyani PP, Rana SK. Integrating ethnobiological knowledge into biodiversity conservation in the eastern Himalayas. J Ethnobiol Ethnomed. 2017;13(1):21.

56. Bonou-Zin RDC, Allali K, Tovignan SD, Yabi JA, Houessionon P. Drivers of Farmers' Perception of the Environmental Externalities of Cotton Production Practices in Benin: A Tobit Analysis. JAES.2019;7(2):120-130.

57. Giller KE. Nitrogen Fixation in Tropical Cropping Systems, CAB International Wallingford, UK; 2001.

58. Adjei-Nsiah S, Leeuwis C, Giller KE, Sakyi-Dawson O, Cobbina J, Kuyper TW, Abekoe M and Van Der Werf W. Land tenure and differential soil fertility management practices among native and migrant farmers in Wenchi, Ghana: implications for interdisciplinary action research. NJAS-Wagen J Life Sc. 2004;52(3-4):331-348.

59. Silim NS, Bramel JP, Akonaay HB, Mligo JK, Christiansen JL (2005) Cropping systems, Uses and primary in situ characterization of Tanzania pigeonpea [Cajanus cajan (L.) Millsp.] landraces. Genet Resour Crop Evol. 2005; 52:645-654.

60. Saxena KB. Seed production systems in pigeonpea. Patancheru 502 324. Andhra Pradesh, India: Tropics, International Crops Research Institute for the Semi-Arid; 2006.

61. Mergeai G, Kimani P, Mwang A, Olubayo F, Smith C, Audi P, Baudoin JP, Le Roi A. Survey of pigeonpea production systems, utilization and marketing in semi-arid lands of Kenya. Biotechnol Agron Soc Environ. 2001; 5:145-53.

62. Kaoneka SR, Saxena RK, Silim SN, Odeny DA, Rao NVPRG, Shemelis HA, Siambi M, Varshney RK. Pigeon pea breeding in eastern and southern Africa: challenges and opportunities. Plant Breed. 2016; 135:148-154.

63. Norton GW, Rajotte EG, Gapud V. Participatory research in integrated pest management: Lessons from the IPM CRSP. Agr Human Values. 1999; 16:431-439.

64. Eneh OC. Enhancing Africa's environmental management: Integrated Pest Management for minimizing of agricultural pesticides pollution. Res J Environ Sci. 2011; 5:521-529.

65. Baco MN, Ahanchedé A, Bello S, Dansi A, Vodouhè R, Biaou G, Lescure JP. Evaluation des pratiques de gestion de la diversité du niébé (Vigna unguiculata): une tentative méthodologique expérimentale au Benin. Cah Agric. 2008; 17:183-188.

66. Assogba P, Dansi A, Dansi M, Ewèdjè E-EBK, Loko YL, Sanni A (2015) Indigenous knowledge and agro-morphological evaluation of the minor crop Kersting's groundnut (Macrotyloma geocarpum (Harms) Marechal et Baudet) cultivars of Benin. Genet Resour Crop Evol. 635:513-529.

Page 16/31 
67. Shiferaw B, Silim S, Muricho G, Audi P, Mligo J, Lyimo S, You L and Christiansen JL. Assessment of the adoption and impact of improved pigeonpea varieties in Tanzania. J SAT Agric Res. 2005; 3:1-7.

68. Changaya AG. Developing of high yielding pigeonpea [Cajanus cajan] germplasm with resistance to Fusarium wilt [Fusarium udum] in Malawi. PhD Thesis, University of KwaZulu-Natal; 2007.

69. Ogbe FMD and Bamidele JF. Potential of pigeonpea [Cajanus cajan] for planted fallow in Edo State, Nigeria. Asian J. Plant Sci. 2007; 6:490-495.

70. Odjo TC, Dossou-Aminon I, Dansi A and Djengue HW. Diversity, Genetic Erosion and Participatory Evaluation of Rice (Oryza sativa L. and Oryza glaberrima Steud) Varieties in Benin, Int. j. curr. res. biosci. plant biol. 2017; 4(4):147-164.

71. Kombo GR, Dansi A, Loko LY, Orkwor GC, Vodouhé R, Assogba P, Magema JM. Diversity of cassava (Manihot esculenta Crantz) cultivars and its management in the department of Bouenza in the Republic of Congo. Genet Resour Crop Evol. 2012; 59(8):1789-1803.

72. Gao XP, Zou CQ, Fan XY, Zhang FS, Hoffland E. From flooded to aerobic conditions in rice cultivation: consequences for zinc uptake. Plant Soil. 2006; 280:41-47.

73. Kreye C, Bouman BAM, Castañeda AR, Lampayan RM, Faronilo JE, Lactaoen A, Fernandez L. Possible causes of yield failure in tropical aerobic rice. Field Crops Res. 2009; 111:197-206.

\section{Tables}

Table 1 Basic information regarding the biophysical characteristics of the surveyed zones

\begin{tabular}{|c|c|c|c|}
\hline Variables & Guinean zone & Sudano- Guinean zone & Sudanian zone \\
\hline Altitude (in m) & $56-223$ & $153-308$ & 214- 609 \\
\hline $\begin{array}{l}\text { Annual rainfall } \\
(\mathrm{mm})\end{array}$ & 1200- 1500 & 1100- 1300 & $900-1100$ \\
\hline $\begin{array}{l}\text { Temperature } \\
\left({ }^{\circ} \mathrm{C}\right)\end{array}$ & 24- 30 & 25- 34 & $21-35$ \\
\hline Seasons & $\begin{array}{l}\text { Bimodal rainfall } \\
\text { regime: } 2 \text { dry seasons and } 2 \text { rainy } \\
\text { seasons }\end{array}$ & $\begin{array}{l}\text { Bimodal rainfall } \\
\text { regime: } 2 \text { dry seasons } \\
\text { and } 2 \text { rainy seasons }\end{array}$ & $\begin{array}{l}\text { Unimodal } \\
\text { rainfall regime: } 1 \text { dry } \\
\text { season and } 1 \text { rainy season }\end{array}$ \\
\hline Dominant soils & Ferrallitic soils & $\begin{array}{l}\text { Ferruginous and } \\
\text { ferrallitic soils }\end{array}$ & $\begin{array}{l}\text { Concreted or hardened } \\
\text { ferruginous } \\
\text { soils with small deep }\end{array}$ \\
\hline $\begin{array}{l}\text { Number of } \\
\text { surveyed } \\
\text { villages }\end{array}$ & 20 & 19 & 11 \\
\hline $\begin{array}{l}\text { Surveyed } \\
\text { sociolinguistic } \\
\text { groups }\end{array}$ & $\begin{array}{l}\text { Biali (Exotic), Somba (Exotic), Fon, } \\
\text { Holly, Mahi, Nago, Idaasha }\end{array}$ & $\begin{array}{l}\text { Adja, Fon, Holly, Mahi, } \\
\text { Nago, Yoruba }\end{array}$ & $\begin{array}{l}\text { Bariba, Dendi, Peuhl, } \\
\text { Yoruba (Exotic), Boo }\end{array}$ \\
\hline
\end{tabular}


Table 2 Socio-demographic characteristics of the surveyed pigeonpea producers across agro-ecological zones of Benin

\begin{tabular}{|c|c|c|c|c|c|}
\hline Variables & $\begin{array}{c}\text { GZ } \\
(n=190)\end{array}$ & $\begin{array}{c}\text { SGZ } \\
(n=200)\end{array}$ & $\begin{array}{c}\text { SZ } \\
(n=110)\end{array}$ & $\begin{array}{l}\text { Overall } \\
(n=500)\end{array}$ & Diff \\
\hline \multicolumn{6}{|l|}{ Gender (\%) } \\
\hline Male & $56.9^{\mathrm{a}}$ & $66^{\mathrm{a}}$ & $65.5^{\mathrm{a}}$ & 62.4 & ns \\
\hline Female & $41.2^{\mathrm{a}}$ & $44^{\mathrm{a}}$ & $34.6^{\mathrm{a}}$ & 37.6 & \\
\hline \multicolumn{6}{|c|}{ Education level (\%) } \\
\hline None & $56.9^{\mathrm{a}}$ & $39^{b}$ & $28.2^{\mathrm{b}}$ & 43.4 & $* * *$ \\
\hline Primary & $27.9^{a}$ & $34^{\mathrm{a}}$ & $33.6^{\mathrm{a}}$ & 31.6 & ns \\
\hline Secondary & $15.3^{\mathrm{c}}$ & $27^{b}$ & $38.2^{\mathrm{a}}$ & 25 & $* * *$ \\
\hline \multicolumn{6}{|l|}{ Age (years) } \\
\hline Average & $48.7^{\mathrm{a}}$ & $44^{\mathrm{b}}$ & $44.5^{\mathrm{b}}$ & 45.9 & $* * *$ \\
\hline Range & $30-69$ & $21-76$ & $26-65$ & $21-76$ & \\
\hline \multicolumn{6}{|c|}{ Experience (years) } \\
\hline Average & $18.4^{\mathrm{a}}$ & $16.5^{\mathrm{b}}$ & $6^{\mathrm{c}}$ & 15 & $* * *$ \\
\hline Range & $10-45$ & $10-50$ & $3-7$ & $3-50$ & \\
\hline \multicolumn{6}{|c|}{ Household size (units) } \\
\hline Average & $6.6^{\mathrm{a}}$ & $6.1^{\mathrm{a}}$ & $6.4^{\mathrm{a}}$ & 6.4 & ns \\
\hline Range & $3-11$ & $3-11$ & $4-10$ & $3-11$ & \\
\hline
\end{tabular}

GZ: Guinean zone; SGZ: Sudano-Guinean Zone; SZ: Sudanean Zone; For the same variable, averages that do not have common letters are statistically different $(\mathrm{p}<0.05) ;{ }^{* * *} \mathrm{p} \square 0.001$; ns : non-significant difference at the $5 \%$ level.

Table 3 Pigeonpea generic names variation across sociolinguistic groups 


\begin{tabular}{lll}
\hline Sociolinguistic groups & Designations & Meanings \\
\hline Adja & Ekloui, Kloui & Common name \\
Bariba, Peulh & Wotiri & Pod-producing erected tree \\
Biali & Tissi Tounan & Referring to cowpea \\
Boo & Blacia & Referring to cowpea \\
Fon, Mahi & Hounkoun, Kloué, Klouékoun & Referring to cowpea \\
Holly, Yoruba & Otini & Common name \\
Idaasha & Colo & Common name \\
Nago, Dendi & Otili & Pod-producing tree \\
Somba & Itoun & Referring to cowpea \\
\hline
\end{tabular}

Table 4 Meaning of pigeonpea vernacular names across study area 


\begin{tabular}{|c|c|c|c|}
\hline $\begin{array}{l}\text { Criteria of } \\
\text { denomination }\end{array}$ & $\begin{array}{c}\% \text { of } \\
\text { vernacular } \\
\text { names }\end{array}$ & Vernacular names & $\begin{array}{l}\text { Meaning of the } \\
\text { vernacular name }\end{array}$ \\
\hline $\begin{array}{l}\text { Morphological } \\
\text { aspect } \\
\text { (seed coat } \\
\text { colour and } \\
\text { size, } \\
\text { eyes colour) }\end{array}$ & 71 & $\begin{array}{l}\text { Colo founfoun, Ekloui koudji, Ekloui ri, Hounkoun } \\
\text { wéwé, Klouékoun wéwé, Klouékoun wéwété } \\
\text { Otili founfoun, Otini founfoun, Wotiri gbika, Wotiri } \\
\text { goukorou } \\
\text { Ekloui djou, Otini dudu } \\
\text { Colo kpikpa, Hounkoun vôvô, Klouékoun vôvô, Otili } \\
\text { kpoukpa, Otini kpoukpa, Wotiri souan } \\
\text { Egblèjin, Ekloui wlanwlan, Klouékoun wlanwlan, Otini } \\
\text { tchofiti, Wotiri wonka } \\
\text { Klouékoun wéwé noukoun vôvô, } \\
\text { Klouékoun wéwé noukoun wiwi } \\
\text { Otili founfoun lakoun, } \\
\text { Otili founfoun kékélé } \\
\text { Ekloui wliwlito }\end{array}$ & $\begin{array}{l}\text { Red pigeonpea } \\
\text { Mottled pigeonpea } \\
\text { Cream pigeonpea } \\
\text { with red eyes } \\
\text { Cream pigeonpea } \\
\text { with black eyes } \\
\text { High sized cream } \\
\text { pigeonpea } \\
\text { Small sized cream } \\
\text { pigeonpea } \\
\text { Small sized }\end{array}$ \\
\hline Seed origin & 8.4 & $\begin{array}{l}\text { Adja klouékoun, Adja kloui } \\
\text { CA monlikoun } \\
\text { Carder kloui, Carder kloui } \\
\text { Djidja kloui } \\
\text { Yovo kloui }\end{array}$ & $\begin{array}{l}\text { Pigeonpea from Adja } \\
\text { Pigeonpea introduced } \\
\text { by CA } \\
\text { Pigeonpea introduced } \\
\text { by Carder } \\
\text { Pigeonpea from Djidja } \\
\text { Pigeonpea introduced } \\
\text { by the Europeans }\end{array}$ \\
\hline $\begin{array}{l}\text { Vegetative } \\
\text { cycle }\end{array}$ & 10.3 & $\begin{array}{l}\text { Bogan } \\
\text { Kpèdovinon ovo, Kpèkloué } \\
\text { Nontchiovi ekloui, Nontchiovi kloui } \\
\text { Wlétchivé kloui }\end{array}$ & $\begin{array}{l}\text { Long vegetative cycle } \\
\text { pigeonpea } \\
\text { Short vegetative cycle } \\
\text { pigeonpea } \\
\text { Orphan pigeonpea } \\
\text { Pigeonpea producing } \\
\text { twice a vear }\end{array}$ \\
\hline Plant type & 3.7 & $\begin{array}{l}\text { Gbomandoui, Ladja kloui } \\
\text { Wotiri }\end{array}$ & $\begin{array}{l}\text { Tall pigeonpea } \\
\text { Pod-producing } \\
\text { erected tree }\end{array}$ \\
\hline $\begin{array}{l}\text { Belonging to } \\
\text { Cowpea }\end{array}$ & 6.5 & Itoun, Tissi tounan, Blacia & Referring to cowpea \\
\hline
\end{tabular}


Table 5 Distribution and extent of cultivated pigeonpea landraces across the ecological zones of Benin 
Klouékoun wéwé nounkoun wiwi (Mahi and Fon sociolinguistic groups)

Klouékoun wéwé noukoun vôvô (Mahi and Fon sociolinguistic groups)

Klouékoun wéwé tété (Mahi sociolinguistic group)

Wlétchivé kloui (Adja sociolinguistic group)

Klouékoun wlanwlan (Fon sociolinguistic group)

Colo kpikpa (Idaasha sociolinguistic group)

Klouékoun vôvô (Fon and Mahi

sociolinguistic groups)

Otili kpoukpa (Nago sociolinguistic group)

Otini kpoukpa (Holly sociolinguistic group)

Otili founfoun kékélé (Idaasha sociolinguistic group)

Otili founfoun lakoun (Idaasha

sociolinguistic group)

Carder ekloui (Adja sociolinguistic group)

Ekloui djou (Adja sociolinguistic group)

Wotiri souan (Bariba sociolinguistic group)

Wotiri wonka (Bariba sociolinguistic group)
Cream seed coat with black eye

Cream seed coat with red eye and intermediate size

Cream seed coat

Cream seed coat and highly mottled

Cream seed coat and mottled

Brown seed coat

Red seed coat

Light seed coat red

Blackish seed coat

Cream seed coat with red eye and small size

Cream seed coat with red eye and high size

Cream seed coat and mottled with high size

Black seed coat and mottled

Red seed coat and mottled

Purple seed coat and mottled

Total
GZ $\quad$ SGZ SZ

NA M-S-m NA 100

$\mathrm{M}+\mathrm{S}+\mathrm{M}+\mathrm{S}+\mathrm{M}+\mathrm{S}+\quad 0$

M-S- ${ }^{m} \quad \mathrm{M}-\mathrm{S}+\quad$ NA $\quad 50$

M-S- ${ }^{m} \quad$ M+S- NA 50

NA M+S- $\mathrm{M}-\mathrm{S}+\quad 0$

NA M-S-m NA 100

M-S- $m$ M-S- m M-S- m 100

M-S- $m$ M-S- $m \quad$ NA 100

NA M-S- $m \quad$ NA 100

$\mathrm{M}-\mathrm{S}+\mathrm{M}-\mathrm{S}+\mathrm{M}+\mathrm{S}+\quad 0$

M-S- $m$ M-S- $m \quad$ NA 100

M-S- $\mathrm{m} \quad \mathrm{NA} \quad \mathrm{NA} \quad 100$

M-S- $m \quad$ NA M-S- $m \quad 100$

NA NA M-S- m 100

NA NA M-S- m 100

$9 / 15 \quad 11 / 15 \quad 7 / 15 \quad-$

$\mathrm{M}+\mathrm{S}+$ : many households on a large areas; $\mathrm{M}+\mathrm{S}$ : many households on a small areas; M-S +: few households on a large areas; M-S-: few households on a small area; GZ: Guinean Zone; SGZ: Sudano-Guinean Zone; SZ: Sudanian Zone; FD: Frequency of Disappearance; m: landrace threatened to disappear. FD = $(\mathrm{z} / \mathrm{Z}) * 100 \mathrm{Where}$ : $\mathrm{z}=$ Number of landraces threatened to disappear (cultivated by few households in a small areas) and $\mathrm{Z}=$ total landrace identified in the ecological zone; NA: Not Available.

Table 6 Reasons for pigeonpea production and use category in Benin 


\begin{tabular}{llcccccc}
\hline Criteria & Variables & \multicolumn{2}{c}{ GZ } & \multicolumn{2}{c}{ SGZ } & \multicolumn{2}{c}{ SZ } \\
& & \multicolumn{2}{c}{$\mathrm{n}=190$} & $\mathrm{n}=200$ & $\mathrm{n}=110$ \\
\cline { 3 - 8 } Reasons & & $\mathrm{F}$ & $\mathrm{FL}$ & $\mathrm{I} \mathrm{p}$ & $\mathrm{FL}$ & $\mathrm{I} \mathrm{p}$ & $\mathrm{FL}$ \\
& Market value & 107 & 37.8 & 80 & 29.6 & 66 & 24.1 \\
& Nutritional value & 176 & 62.2 & 190 & 70.4 & 98 & 35.8 \\
& Land fertilizing power & - & - & - & - & 110 & 40.2 \\
& EF & 283 & - & 270 & - & 274 & - \\
Use category & Consumption & 164 & 34.8 & 188 & 38 & 96 & 31.9 \\
& Medicine & 92 & 19.5 & 75 & 15.2 & 72 & 23.9 \\
& Offering & - & - & 7 & 1.4 & - & - \\
& Sacrifice & - & - & 5 & 1 & - & - \\
& Weed control & 15 & 3.2 & 19 & 3.8 & 23 & 7.6 \\
& Grain processing & 20 & 4.2 & 10 & 2 & - & - \\
& Fertilization & 181 & 38.4 & 191 & 38.6 & 110 & 36.5 \\
& EF & 472 & - & 495 & - & 301 & - \\
\hline
\end{tabular}

GZ: Guinean zone; SGZ: Sudano-Guinean zone; SZ: Sudanian zone; $\mathrm{n}=$ Number of respondents; FL = Fidelity Level, $\mathrm{F}=$ number of respondents for a modality of use or reason that motivates the culture and $\Sigma \mathrm{F}=$ sum of the number of respondents for all modalities of use or reason

Table 7 Biophysical resources, cultural practices and seed system across ecological zones 


\begin{tabular}{|c|c|c|c|c|c|}
\hline Variables & $\begin{array}{c}\text { GZ } \\
(n=190)\end{array}$ & $\begin{array}{c}\text { SGZ } \\
(n=200)\end{array}$ & $\begin{array}{c}\text { SZ } \\
(n=110)\end{array}$ & $\begin{array}{l}\text { Overall } \\
(n=500)\end{array}$ & diff \\
\hline \multicolumn{6}{|l|}{ Cropping area in 2015 (ha) } \\
\hline Average & $0.9 \pm 0.2^{b}$ & $1.3 \pm 0.8^{\mathrm{a}}$ & $0.3 \pm 0.1^{\mathrm{c}}$ & $0.9 \pm 0.6$ & $* * *$ \\
\hline Range & $0.5-1.3$ & $0.5-2.5$ & $0.3-0.5$ & $0.3-2.5$ & \\
\hline \multicolumn{6}{|l|}{ Cropping area in 2016 (ha) } \\
\hline Average & $0.8 \pm 0.1^{b}$ & $0.9 \pm 0.4^{\mathrm{a}}$ & $0.4 \pm 0.1^{\mathrm{c}}$ & $0.7 \pm 0.3$ & $* * *$ \\
\hline Range & $0.5-1$ & $0.5-1.5$ & $0.3-1$ & $0.3-1.5$ & \\
\hline \multicolumn{6}{|l|}{ Cropping area in 2017 (ha) } \\
\hline Average & $0.5 \pm 0.1^{\mathrm{b}}$ & $0.7 \pm 0.3^{\mathrm{a}}$ & $0.4 \pm 0.1^{\mathrm{c}}$ & $0.6 \pm 0.3$ & $* * *$ \\
\hline Range & $0.6-0.8$ & $0.5-1.25$ & $0.3-0.8$ & $0.3-1.3$ & \\
\hline \multicolumn{6}{|l|}{ Source of labour (\%) } \\
\hline Family labour & $12.1^{b}$ & $13.5^{\mathrm{b}}$ & $49.3^{\mathrm{a}}$ & 13.2 & $* * *$ \\
\hline Family and friends labour & $87.9^{\mathrm{a}}$ & $61.5^{\mathrm{b}}$ & $42.2^{\mathrm{c}}$ & 73 & $* * *$ \\
\hline Family friends and jobber labour & - & $25^{\mathrm{a}}$ & $8.5^{\mathrm{b}}$ & 13.8 & $* * *$ \\
\hline \multicolumn{6}{|l|}{ Seed system (\%) } \\
\hline Seeds of previous harvests & $70^{\mathrm{a}}$ & $62.9^{\mathrm{a}}$ & $46.2^{\mathrm{b}}$ & 60.2 & $* * *$ \\
\hline Seeds of friends & $9.2^{\mathrm{b}}$ & $10.5^{b}$ & $50.4^{\mathrm{a}}$ & 22 & $* * *$ \\
\hline Market Seeds & $20.8^{\mathrm{a}}$ & $26.7^{\mathrm{a}}$ & $3.4^{\mathrm{b}}$ & 17.8 & $* * *$ \\
\hline Conservation method & $3.7^{\mathrm{a}}$ & $4.5^{\mathrm{a}}$ & - & 3.2 & ns \\
\hline Seed storage & $70^{b}$ & $84^{\mathrm{a}}$ & $34.6^{\mathrm{c}}$ & 67.8 & $* * *$ \\
\hline Seed purchase & $30^{b}$ & $16^{\mathrm{c}}$ & $65.5^{\mathrm{a}}$ & 32.2 & $* * *$ \\
\hline \multicolumn{6}{|l|}{ Plant type (\%) } \\
\hline Annual plant & $92.1^{\mathrm{b}}$ & $90.5^{b}$ & $100^{\mathrm{a}}$ & 93.2 & $* * *$ \\
\hline Perennial plant & $7.9^{\mathrm{a}}$ & $9.5^{\mathrm{a}}$ & - & 6.8 & ns \\
\hline \multicolumn{6}{|l|}{ Land type (\%) } \\
\hline Intercropping system & $100^{\mathrm{a}}$ & $98.5^{\mathrm{b}}$ & $24.6^{\mathrm{c}}$ & 82.8 & $* * *$ \\
\hline Pure stand & - & $1.5^{\mathrm{b}}$ & $75.4^{\mathrm{a}}$ & 17.2 & $* * *$ \\
\hline \multicolumn{6}{|c|}{ Land, pests and diseases management (\%) } \\
\hline Fertilization & - & - & - & - & ns \\
\hline Use of pesticides & - & - & 63.7 & 14 & $* * *$ \\
\hline \multicolumn{6}{|l|}{ Sowing period (\%) } \\
\hline April - June & $97.9^{\mathrm{a}}$ & $91^{\mathrm{b}}$ & - & 73.6 & $* * *$ \\
\hline April - May & $2.1^{\mathrm{a}}$ & $9^{b}$ & - & 4.4 & $* * *$ \\
\hline June - August & - & - & 68.2 & 15 & $* * *$ \\
\hline July - August & - & - & 31.8 & 7 & $* * *$ \\
\hline \multicolumn{6}{|l|}{ Farming activities (\%) } \\
\hline Ploughing & $65.8^{\mathrm{b}}$ & $83^{a}$ & $72.7^{b}$ & 74.2 & $* * *$ \\
\hline Sowing & $100^{\mathrm{a}}$ & $100^{\mathrm{a}}$ & $100^{\mathrm{a}}$ & 100 & ns \\
\hline Weed control & $100^{\mathrm{a}}$ & $100^{\mathrm{a}}$ & $100 a$ & 100 & ns \\
\hline Pod harvest & $92.6^{\mathrm{b}}$ & $97.5^{\mathrm{a}}$ & $87.3^{\mathrm{b}}$ & 93.4 & $* * *$ \\
\hline Pod plugging & $84.7^{b}$ & $96^{\mathrm{a}}$ & $80.9^{b}$ & 88.4 & $* * *$ \\
\hline Winnowing & $52.1^{\mathrm{b}}$ & $17^{\mathrm{C}}$ & $74.5^{\mathrm{a}}$ & 43 & $* * *$ \\
\hline Yield (kg/ha) & & & & & \\
\hline
\end{tabular}




\begin{tabular}{lcccc} 
Average & $557.5 \pm 15.9^{\mathrm{a}}$ & $566.6 \pm 35.8^{\mathrm{b}}$ & $522.3 \pm 44^{\mathrm{c}}$ & $553.4 \pm 36.3$ \\
Range & $450-560$ & $550-650$ & $450-560$ & $450-650$ \\
\hline
\end{tabular}

GZ: Guinean zone; SGZ: Sudano-Guinean Zone; SZ: Sudanean Zone; n: Number of respondents; diff: Difference; for the same variable, means or percentages that don't have common letters are statistically different $(p<0.05)$; ***p $\square 0.001$; ns: non-significant difference at the $5 \%$ level

Table 8 Comparative table of pigeonpea production constraints across ecological zones

\begin{tabular}{lcccccccc}
\hline Constraints & \multicolumn{4}{c}{ Overall } & \multicolumn{4}{c}{ Rank per zone } \\
& \multicolumn{1}{c}{ TNVMACPCO } & Imp & Rank & GZ & SGZ & SZ \\
Long vegetative cycle & 50 & 28 & 48 & 42 & 1 & 1 & 1 & 3 \\
Pests and diseases & 48 & 14 & 48 & 36.7 & 2 & 2 & 2 & 1 \\
Rainfall irregularity & 30 & 3 & 25 & 19.3 & 3 & 3 & 4 & 4 \\
Weeding & 25 & 1 & 23 & 16.3 & 5 & 4 & 5 & 6 \\
Lack of improved varieties & 26 & - & 24 & 16.7 & 4 & 5 & 3 & 5 \\
Storage insects & 10 & - & 7 & 5.7 & 8 & 6 & 9 & 8 \\
Soil poverty & 15 & 3 & 13 & 10.3 & 6 & 7 & 8 & 2 \\
Harvest and post-harvest work & 10 & 1 & 4 & 5 & 9 & 8 & 9 & 7 \\
Low productivity & 11 & - & 10 & 7 & 7 & 9 & 6 & 6 \\
Lack of cultivable land & 5 & - & 3 & 2.7 & 10 & 10 & 7 & 9 \\
\hline
\end{tabular}

GZ: Guinean zone; SGZ: Sudano-Guinean zone; SZ: Sudanian zone; TNV: Total Number of Villages in which the constraint is cited; MAC: Number of villages where the constraint is the major one or ranked first; PCO: number of villages in which the constraint was classified among the principal constraints i.e. among the first five; Imp: Importance

Table 9 Evaluation of pests and diseases impact in pigeonpea production 


\begin{tabular}{llccccc}
\hline Evaluation (\% of responses) & Variables & $\begin{array}{c}\text { Overall } \\
(\mathrm{n}=500)\end{array}$ & $\begin{array}{c}\text { GZ } \\
(\mathrm{n}=190)\end{array}$ & $\begin{array}{c}\text { SGZ } \\
(\mathrm{n}=200)\end{array}$ & $\begin{array}{c}\text { SZ } \\
(\mathrm{n}=110)\end{array}$ & $\begin{array}{c}\text { Diff } \\
\text { Impact on pigeonpea yield }\end{array}$ \\
& None & 12.8 & $18.4^{\mathrm{b}}$ & $28.5^{\mathrm{a}}$ & $2.7^{\mathrm{c}}$ & $*^{* * *}$ \\
& Low & 51.3 & $52.6^{\mathrm{a}}$ & $42.5^{\mathrm{b}}$ & $1.8^{\mathrm{c}}$ & $* * *$ \\
& Average & 32.1 & $29^{\mathrm{a}}$ & $29^{\mathrm{a}}$ & $9.1^{\mathrm{b}}$ & $* * *$ \\
& High & 2.6 & - & - & 81.8 & $* * *$ \\
& Very high & 1.3 & - & - & 4.6 & $* * *$ \\
Control of pests and diseases & Absence of control & & - & - & 36.3 & $* * *$ \\
& Use of cotton pesticides & & - & - & 63.7 & $* * *$ \\
\hline
\end{tabular}

GZ: Guinean zone; SGZ: Sudano-Guinean zone; SZ: Sudanian zone; n: Number of respondents; Diff: difference; for the same variable, means or percentages that have no common letters are statistically different $(p<0.05)$; ***p $\square 0.001$; ns: non-significant difference at the $5 \%$ level.

Table 10 Farmers' preference criteria of pigeonpea across ecological zones

\begin{tabular}{lccccccccc}
\hline Preference criteria & \multicolumn{4}{c}{ Overall } & \multicolumn{3}{c}{ Rank per zone } \\
\cline { 2 - 9 } & TNV & MCR & PCr & Imp & Rank & GZ & SGZ & SZ \\
Precocity & 50 & 23 & 49 & 40.7 & 1 & 1 & 1 & 3 \\
Resistance to pests and diseases & 45 & 16 & 45 & 35.3 & 2 & 2 & 2 & 1 \\
Short cooking time & 39 & 0 & 30 & 23 & 4 & 3 & 5 & 5 \\
Adaptability to any type of soil & 28 & 5 & 25 & 19.3 & 6 & 4 & 8 & 2 \\
Good taste & 38 & 0 & 35 & 24.3 & 3 & 5 & 4 & 4 \\
High productivity & 35 & 3 & 23 & 20.3 & 5 & 6 & 3 & 7 \\
Cultivable at any time of the year & 22 & 1 & 10 & 11 & 7 & 7 & 7 & 8 \\
High market value & 11 & 2 & 10 & 7.7 & 8 & 8 & 6 & - \\
Resistance to storage insects & 10 & 0 & 5 & 5 & 9 & 9 & 10 & 6 \\
Easy for ginning & 6 & 0 & 1 & 2.3 & 11 & 10 & - & 10 \\
Drought resistance & 11 & 0 & 3 & 4.7 & 10 & 10 & 9 & 9 \\
\hline
\end{tabular}

GZ: Guinean zone; SGZ: Sudano-Guinean zone; SZ: Sudanian zone; TNV: Total Number of Villages in which the criterion is cited; MCR: Number of villages where the criterion is the major one or ranked first; PCr: number of villages in which the criterion was classified among the principal criterion i.e. among the first five; Imp: Importance

Table 11 Importance (in rank) of varietal preference criteria across different sociolinguistic groups 


\begin{tabular}{|c|c|c|c|c|c|c|c|c|c|c|c|c|c|}
\hline $\begin{array}{l}\text { Preference } \\
\text { criteria }\end{array}$ & Adja & Bariba & Biali & Boo & Dendi & Fon & Holly & Idaasha & Mahi & Nago & Peuhl & Somba & Yorouba \\
\hline Precocity & 1 & 1 & 1 & 1 & 1 & 1 & 1 & 1 & 1 & 3 & 1 & 1 & 1 \\
\hline $\begin{array}{l}\text { Resistance } \\
\text { to pests and } \\
\text { diseases }\end{array}$ & 2 & 1 & - & 1 & 1 & 2 & 1 & 1 & 2 & 3 & 1 & 1 & 1 \\
\hline $\begin{array}{l}\text { Short } \\
\text { cooking } \\
\text { time }\end{array}$ & 2 & 1 & - & 1 & 1 & 3 & 1 & 2 & 2 & 2 & 1 & - & 1 \\
\hline $\begin{array}{l}\text { Adaptability } \\
\text { to any type } \\
\text { of soil }\end{array}$ & 5 & 1 & 1 & 1 & 1 & 5 & 2 & - & 5 & 1 & 1 & - & 1 \\
\hline Good taste & 4 & 1 & 1 & 1 & 1 & 2 & 1 & & 3 & 2 & 1 & 1 & 2 \\
\hline $\begin{array}{l}\text { High } \\
\text { productivity }\end{array}$ & 3 & 2 & 1 & 2 & 1 & 2 & 3 & 2 & 2 & 2 & 1 & - & 3 \\
\hline $\begin{array}{l}\text { Cultivable } \\
\text { at any time } \\
\text { of the year }\end{array}$ & 5 & 3 & - & 1 & 1 & 6 & 3 & 2 & 4 & 1 & 2 & - & 1 \\
\hline $\begin{array}{l}\text { High } \\
\text { market } \\
\text { value }\end{array}$ & 6 & - & 1 & - & - & 6 & 2 & 1 & 5 & - & - & 1 & - \\
\hline $\begin{array}{l}\text { Resistance } \\
\text { to storage } \\
\text { insects }\end{array}$ & - & 3 & - & 1 & - & 7 & - & - & 5 & - & 1 & - & 4 \\
\hline $\begin{array}{l}\text { Easy for } \\
\text { ginning }\end{array}$ & 7 & 4 & - & 2 & - & - & - & - & 5 & - & 2 & - & 4 \\
\hline $\begin{array}{l}\text { Drought } \\
\text { resistance }\end{array}$ & - & 2 & - & 2 & - & 4 & - & - & - & - & - & - & 3 \\
\hline
\end{tabular}

Table 12 Agronomic and culinary characteristics of pigeonpea landraces grown accros Benin's ecological zone 


\begin{tabular}{|c|c|c|c|}
\hline $\begin{array}{l}\text { Landraces/Local } \\
\text { names }\end{array}$ & GZ & SGZ & $\mathrm{SZ}$ \\
\hline $\begin{array}{l}\text { CBSL } \\
\text { Klouékoun wéwé } \\
\text { nounkoun wiwi } \\
\text { (Mahi and Fon } \\
\text { sociolinguistic } \\
\text { groups) }\end{array}$ & NA & $\begin{array}{l}\text { High productivity; Long } \\
\text { cooking time; Long } \\
\text { vegetative cycle; Resistant to } \\
\text { diseases and pests; } \\
\text { Susceptible to storage } \\
\text { insects }\end{array}$ & NA \\
\hline $\begin{array}{l}\text { CRISL } \\
\text { Klouékoun wéwé } \\
\text { noukoun vôvô } \\
\text { (Mahi and Fon } \\
\text { sociolinguistic } \\
\text { groups) }\end{array}$ & $\begin{array}{l}\text { High productivity; Long } \\
\text { cooking time; Long } \\
\text { vegetative cycle; Resistant to } \\
\text { diseases and pests; } \\
\text { Susceptible to storage } \\
\text { insects }\end{array}$ & $\begin{array}{l}\text { High productivity; Long } \\
\text { cooking time; Long } \\
\text { vegetative cycle; Resistant to } \\
\text { diseases and pests; } \\
\text { Susceptible to storage } \\
\text { insects }\end{array}$ & $\begin{array}{l}\text { Low productivity; Long } \\
\text { cooking time; Long } \\
\text { vegetative cycle; Resistant to } \\
\text { diseases and pests; } \\
\text { Susceptible to storage insects }\end{array}$ \\
\hline $\begin{array}{l}\text { CSL } \\
\text { Klouékoun wéwé } \\
\text { tété } \\
\text { (Mahi } \\
\text { sociolinguistic } \\
\text { group) }\end{array}$ & $\begin{array}{l}\text { High productivity; Long } \\
\text { cooking time; Long } \\
\text { vegetative cycle; Resistant to } \\
\text { diseases and pests; Resistant } \\
\text { to storage insects }\end{array}$ & $\begin{array}{l}\text { High productivity; Long } \\
\text { cooking time; Long } \\
\text { vegetative cycle; Resistant to } \\
\text { diseases and pests; Resistant } \\
\text { to storage insects }\end{array}$ & NA \\
\hline $\begin{array}{l}\text { CHMSL } \\
\text { Wlétchivé kloui } \\
\text { (Adja } \\
\text { sociolinguistic } \\
\text { group) }\end{array}$ & $\begin{array}{l}\text { Low productivity; Long } \\
\text { cooking time; Long } \\
\text { vegetative cycle; Resistant to } \\
\text { diseases and pests; Resistant } \\
\text { to storage insects }\end{array}$ & $\begin{array}{l}\text { Low productivity; Long } \\
\text { cooking time; Long } \\
\text { vegetative cycle; Resistant to } \\
\text { diseases and pests; Resistant } \\
\text { to storage insects }\end{array}$ & NA \\
\hline $\begin{array}{l}\text { CMSL } \\
\text { Klouékoun } \\
\text { wlanwlan } \\
\text { (Fon } \\
\text { sociolinguistic } \\
\text { group) }\end{array}$ & NA & $\begin{array}{l}\text { Low productivity; Long } \\
\text { cooking time; Long } \\
\text { vegetative cycle; Resistant to } \\
\text { diseases and pests; Resistant } \\
\text { to storage insects }\end{array}$ & $\begin{array}{l}\text { Low productivity; Long } \\
\text { cooking time; Long } \\
\text { vegetative cycle; Susceptible } \\
\text { to diseases and pests; } \\
\text { Resistant to storage insects }\end{array}$ \\
\hline $\begin{array}{l}\text { BWSL } \\
\text { Colo kpikpa } \\
\text { (Idaasha } \\
\text { sociolinguistic } \\
\text { group) }\end{array}$ & NA & $\begin{array}{l}\text { Low productivity; Long } \\
\text { cooking time; Long } \\
\text { vegetative cycle; Resistant to } \\
\text { diseases and pests; Resistant } \\
\text { to storage insects }\end{array}$ & NA \\
\hline $\begin{array}{l}\text { RSL } \\
\text { Klouékoun vôvô } \\
\text { (Fon and Mahi } \\
\text { sociolinguistic } \\
\text { groups) }\end{array}$ & $\begin{array}{l}\text { High productivity; Short } \\
\text { cooking time; Short } \\
\text { vegetative cycle; Resistant to } \\
\text { diseases and pests; Resistant } \\
\text { to storage insects }\end{array}$ & $\begin{array}{l}\text { High productivity; Short } \\
\text { cooking time; Short } \\
\text { vegetative cycle; Resistant to } \\
\text { diseases and pests; Resistant } \\
\text { to storage insects }\end{array}$ & $\begin{array}{l}\text { Low productivity; Short } \\
\text { cooking time; Short } \\
\text { vegetative cycle; Susceptible } \\
\text { to diseases and pests; } \\
\text { Resistant to storage insects }\end{array}$ \\
\hline $\begin{array}{l}\text { LRSL } \\
\text { Otili kpoukpa } \\
\text { (Nago } \\
\text { sociolinguistic } \\
\text { group) }\end{array}$ & $\begin{array}{l}\text { High productivity; Short } \\
\text { cooking time; Short } \\
\text { vegetative cycle; Resistant to } \\
\text { diseases and pests; Resistant } \\
\text { to storage insects }\end{array}$ & $\begin{array}{l}\text { High productivity; Short } \\
\text { cooking time; Short } \\
\text { vegetative cycle; Resistant to } \\
\text { diseases and pests; Resistant } \\
\text { to storage insects }\end{array}$ & NA \\
\hline $\begin{array}{l}\text { BKSL } \\
\text { Otini kpoukpa }\end{array}$ & NA & $\begin{array}{l}\text { Low productivity; Long } \\
\text { cooking time; Long } \\
\text { vegetative cycle; Resistant to }\end{array}$ & NA \\
\hline
\end{tabular}


(Holly

sociolinguistic

group)

CRSSL

Otili founfoun

kékélé

(Idaasha

sociolinguistic

group)

CRHSL

Otili founfoun

lakoun

(Idaasha

sociolinguistic

group)

CMHSL

Carder ekloui

(Adja

sociolinguistic

group)

BMSL

Ekloui djou

(Adja

sociolinguistic

group)

RMSL

Wotiri souan

(Bariba

sociolinguistic

group)

PMSL

Wotiri wonka

(Bariba

sociolinguistic

group)

diseases and pests; Resistant

to storage insects

High productivity; Long

cooking time; Long

vegetative cycle; Resistant to

diseases and pests;

Susceptible to storage

insects

High productivity; Long

cooking time; Long

vegetative cycle; Resistant to

diseases and pests;

Susceptible to storage

insects

High productivity; Short

cooking time; Long

vegetative cycle; Resistant to

diseases and pests; Resistant

to storage insects

High productivity; Long

cooking time; Long

vegetative cycle; Resistant to

diseases and pests; Resistant

to storage insects

NA

NA

NA

NA

NA

NA
High productivity; Long

cooking time; Long

vegetative cycle; Resistant to

diseases and pests;

Susceptible to storage

insects

High productivity; Long

cooking time; Long

vegetative cycle; Resistant to

diseases and pests;

Susceptible to storage

insects

Low productivity; Long

cooking time; Long vegetative cycle; Susceptible to diseases and pests; Resistant to storage insects Low productivity; Long cooking time; Long vegetative cycle; Susceptible to diseases and pests;

Resistant to storage insects

Low productivity; Long cooking time; Long vegetative cycle; Susceptible to diseases and pests; Resistant to storage insects

BKSL: Blackish seeded landrace; BMSL: Black and mottled seeded landrace; BWSL: Brown seeded landrace; CBSL: Cream with black eye seeded landrace; CHMSL: Cream and highly mottled seeded landrace; CMHSL: Cream and mottled with high size seeded landrace; CMSL: Cream and mottled seeded landrace; CRHSL: Cream with red eye and high size seeded landrace; CRISL: Cream with red eye and intermediate size seeded landrace; CRSSL: Cream with red eye and small size seeded landrace; CSL: Cream seeded landrace; LRSL: Light red seeded landrace; PMSL: Purple and mottled seeded landrace; RMSL: Red and mottled seeded landrace; RSL : Red seeded landrace; GZ: Guinean zone; SGZ: Sudano-Guinean zone; SZ: Sudanian zone ; NA : Landrace Absent

\section{Figures}




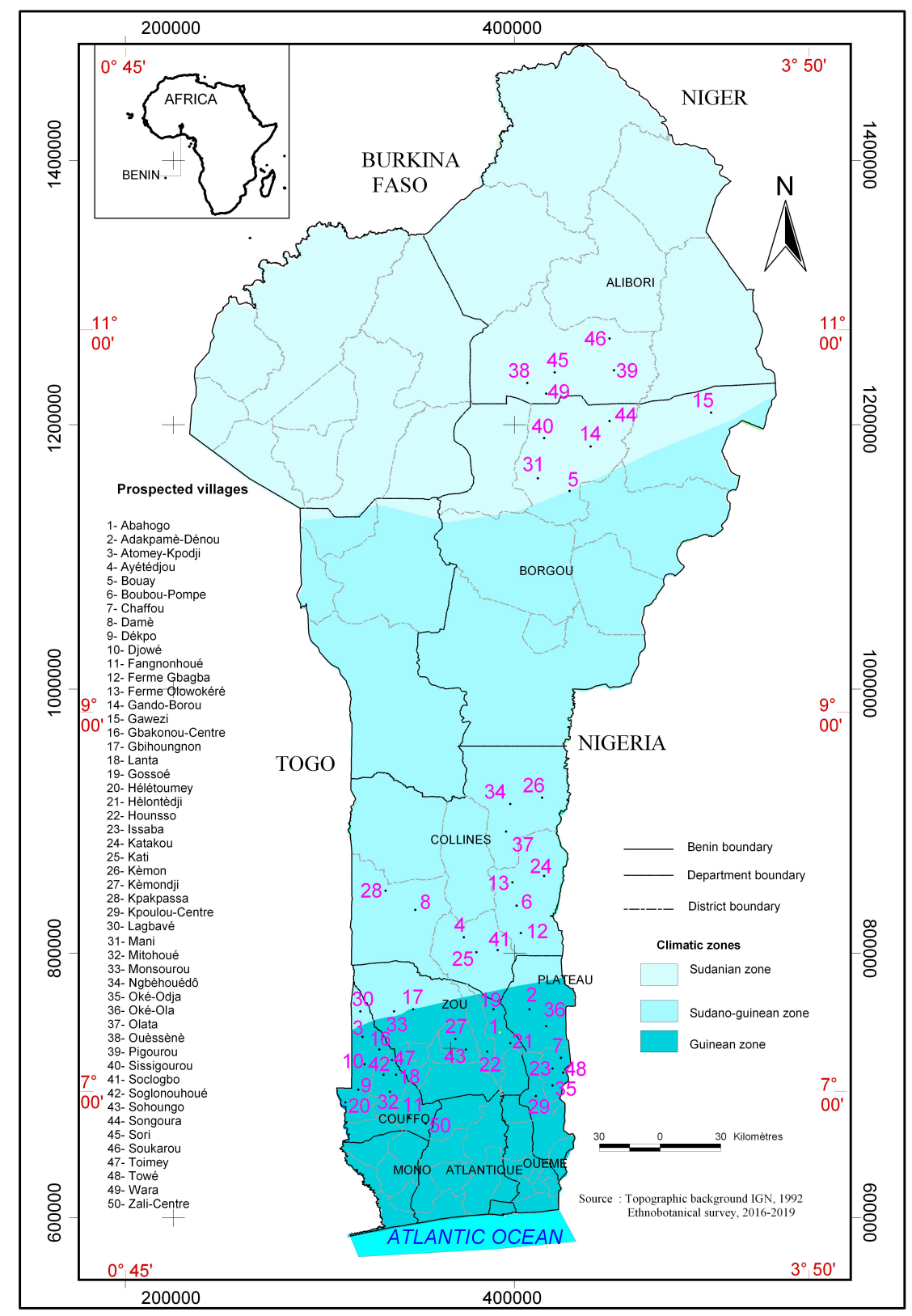

Figure 1

Map of Benin showing the geographical locations of the surveyed villages. 


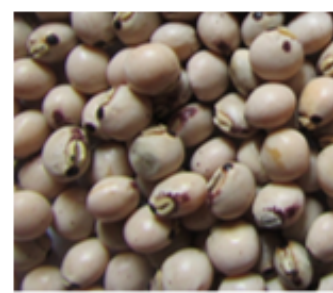

Klouékoun wéwé nounhoun wiwi (Mahi and Fon sociolinguistic groups)

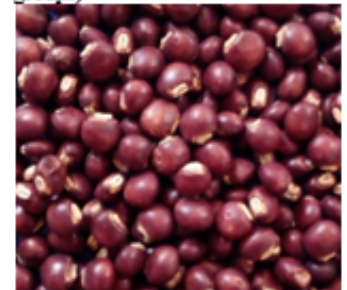

Colo kpikpa (Idaasha

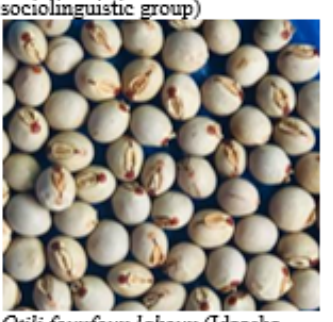

Otili founfoun lakoun (Idaasha

sociolinguistic group)

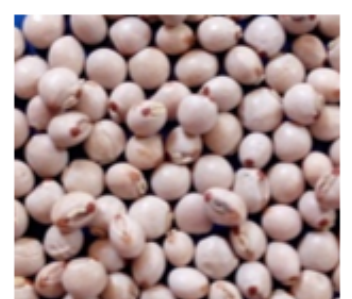

Klouékoun wéwé noukoun vốvó (Mahi and Fon sociolinguistic

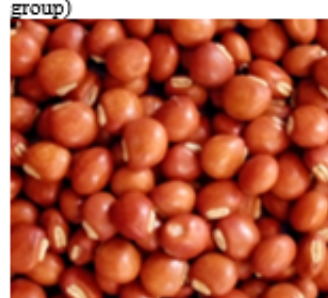

Klouékoun vôvó (Fon and Mahi sociolinguistic groups)

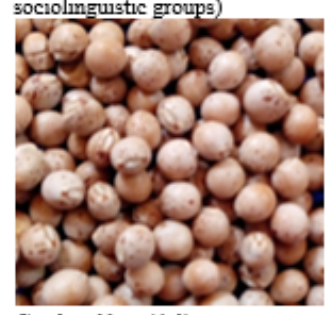

Carder ekloui (Adja sociolinguistic group)

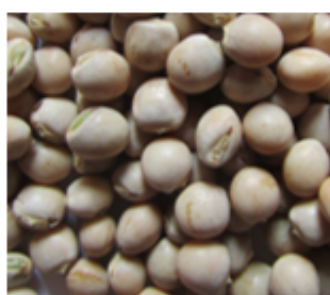

Klouékoun wéwé tété (Mahi sociolinguistic group)

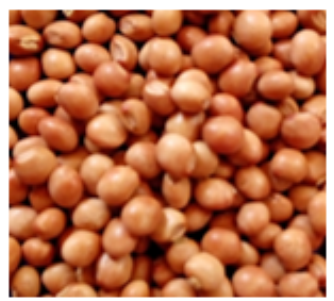

Otili kpoukpa (Nago

sociolinguistic group)

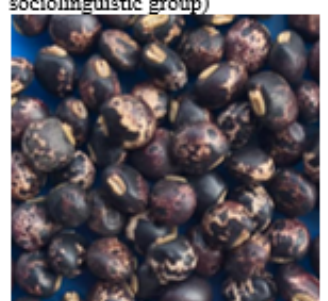

Ekloui djou (Adja sociolinguistic group)

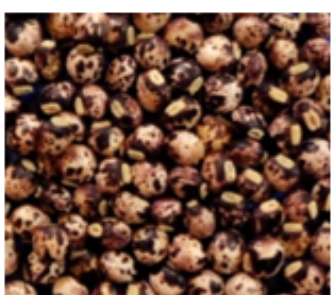

Wlétchivé kloui (Adja sociolinguistic group)

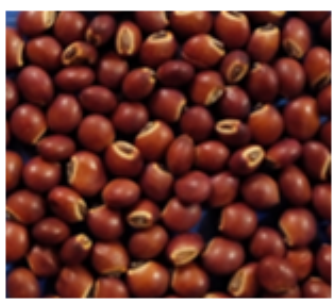

Otini kpoukpa (Holly and Nago sociolinguistic groups)

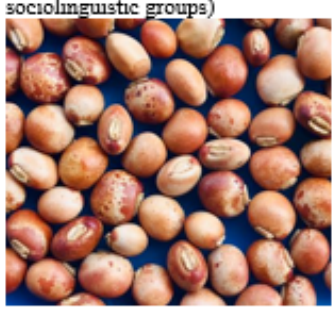

Wotivi souan (Bariba sociolinguistic group)

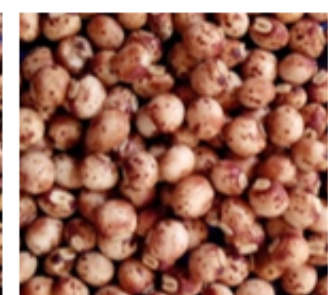

Klouékoun wlanwlan (Fon sociolinguistic group)

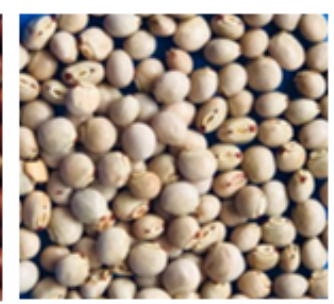

Otili founfoun kékélé (Idaasha sociolinguistic group)

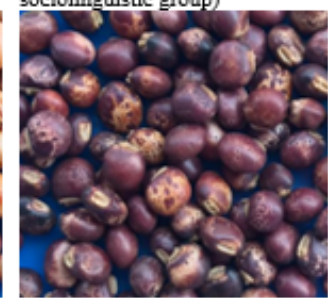

Wotivi wonka (Bariba sociolinguistic group)

Figure 2

Map of Benin showing the geographical locations of the surveyed villages. 